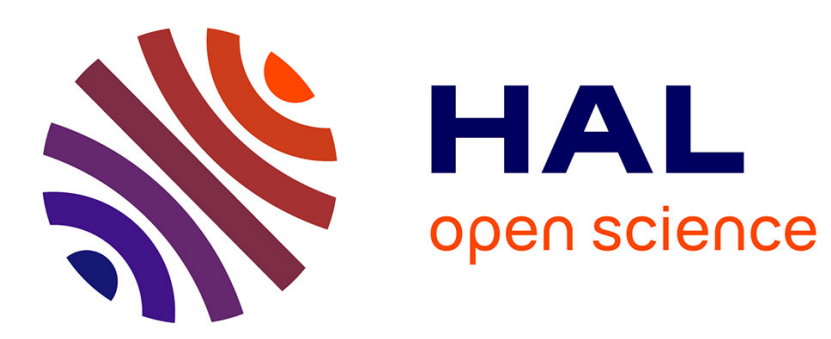

\title{
Shoreface mesoscale morphodynamics: A review
}

Klervi Hamon-Kerivel, Andrew Cooper, Derek Jackson, Mouncef Sedrati, Emilia Guisado Pintado

\section{To cite this version:}

Klervi Hamon-Kerivel, Andrew Cooper, Derek Jackson, Mouncef Sedrati, Emilia Guisado Pintado. Shoreface mesoscale morphodynamics: A review. Earth-Science Reviews, 2020, 209, pp.103330. 10.1016/j.earscirev.2020.103330 . hal-02944352

\section{HAL Id: hal-02944352 \\ https://hal.science/hal-02944352}

Submitted on 8 Oct 2021

HAL is a multi-disciplinary open access archive for the deposit and dissemination of scientific research documents, whether they are published or not. The documents may come from teaching and research institutions in France or abroad, or from public or private research centers.
L'archive ouverte pluridisciplinaire HAL, est destinée au dépôt et à la diffusion de documents scientifiques de niveau recherche, publiés ou non, émanant des établissements d'enseignement et de recherche français ou étrangers, des laboratoires publics ou privés. 
Klervi Hamon-Kerivel (1) *, Andrew Cooper (1,2), Derek Jackson (1,2), Mouncef Sedrati (3), Emilia 3 Guisado Pintado $(4,1)$

4 (1) School of Geography \& Environmental Sciences, Ulster University, Coleraine, UK,

5 (2) Discipline of Geology, University of KwaZulu-Natal, Westville Campus, Private Bag X54001, Durban 6 4000, South Africa

7 (3) Équipe GMGL-Domaines Océaniques UMR 6538, Université de Bretagne Sud, Vannes, France,

8 (4) Geography Regional Analysis and Physical Geography, University of Seville, Seville, Spain

*Corresponding author: School of Geography \& Environmental Sciences, Ulster University, Cromore Road, Coleraine BT52 1SA, UK; Email Address: $\underline{\text { Hamon Kerivel-k@ulster.ac.uk }}$

\section{Abstract}

At seasonal to century timescales (mesoscale), the shoreface is a critical zone seaward of the surf zone and/or beachface, in which waves interact with the mobile seafloor to cause morphological change. This has important (and often unacknowledged) implications for adjacent shoreline form and behaviour both now and in the near-future. The shoreface has been relatively little studied from a mesoscale morphodynamic (morphological change over time) perspective and various definitions exist regarding its extent and morphodynamic subdivisions. To overcome the diversity and ambiguity of existing definitions we propose a standard terminology involving the external limits and subordinate zones of the shoreface.

In our definition, the landward limit of the shoreface coincides with the seaward limit of the fair weather surf zone, and where no surf zone is present, the base of the beachface. The shoreface itself is subdivided into upper and lower shorefaces, separated by the depth of closure (DoC) as defined by Hallermeier (1981). The seaward limit of the lower shoreface is defined by the limit of significant sediment transport, indicated by bed shear stress according to Valiente et al. (2019). All boundaries are temporally variable according to wave characteristics and timescale of study. 
The upper shoreface is dynamic at seasonal to annual timescales and interacts with the adjacent surfzone via wave transformation and two-way sediment exchange. The lower shoreface is dynamic at decadal to millennial timescales and it interacts with the adjacent upper shoreface and inner shelf. The upper shoreface is strongly influenced by wave hydrodynamics whereas the lower shoreface is less dynamic and its shape is more heavily influenced by geological factors (nature and/or abundance of sediment, depth and erodibility of rock outcrop, etc.). Sediment exchange both within the shoreface and between shoreface and adjacent environments is strongly event-driven. Longshore, onshore and offshore transport mechanisms have been documented.

The shoreface profile influences, and is influenced by, wave transformation, however, the widely adopted shoreface equilibrium profile is not universally applicable. Instead, a diversity of shoreface morphologies exists in two and three dimensions. These are likely related to sediment supply and accommodation and we propose a spectrum of shoreface types based on these variables. Recent studies have shown that large-scale 3-D forms (e.g. shoreface-connected ridges and sorted bedforms) strongly influence shoreline behaviour, however, the dynamics of these shoreface bedforms requires further investigation. Each type of shoreface likely exhibits distinctive behaviour at the mesoscale (time scale of $10^{1}$ to $10^{2}$ years and a spatial scale of $10^{1}$ to $10^{2} \mathrm{~km}$ ). This is proposed as a unifying model with which to integrate studies of shoreface dynamics at different spatial and temporal scales.

\section{$44 \quad$ Keywords}

Shoreface morphodynamics

Depth of closure

47 Mesoscale

48 Shoreline 
52

53

The shoreface is a transitional zone between the continental shelf and the shoreline, in which waves (particularly long period waves) begin to strongly interact with the seabed. These shoreface interactions "condition" the waves, altering their deep water parameters, before they reach the surf zone where more significant wave-seabed interactions (attenuation, breaking and generation of secondary wave motions) occur (Wright and Short, 1984). The contemporary shoreface is difficult to access and direct measurements have been eclipsed until recently by a strong scientific and engineering focus on the surf zone and beach face (swash zone) and areas to landward. Geologically, the shoreface comprises a series of sandy deposits which reflect the influence of waves, currents and organisms on the palaeo-environment (Dashtgard et al., 2009; Hampson and Storms, 2003).

The influence of the shoreface on incoming wave transformation, particularly during storms, is widely recognised (Backstrom et al., 2015; Héquette and Hill, 1993; Niedoroda et al., 1984; Swift et al., 1985) and has been the subject of research attention in recent years (Backstrom et al., 2015). Interest has also been stimulated by recognition of the shoreface's role in coastal response to sea-level rise (Cooper et al., 2018) and its role as a reservoir of sediment accumulated during and since the Holocene transgression (Kinsela et al., 2016). Ancient shoreface sediments have also been studied because they can form hydrocarbon reservoirs (Howell et al., 2008). This paper reviews past research and recent progress in understanding the shoreface in the context of the wider coastal system. It reviews linkages between the shoreface and adjacent surf zone and shoreline and explores the variety of shoreface morphologies and the influences upon it such as geological control and sediment availability.

This paper is largely concerned with shoreface morphology and mesoscale (dynamics which corresponds to a time scale of $10^{1}$ to $10^{2}$ years; and a spatial scale of $10^{1}$ to $10^{2} \mathrm{~km}$ ) which is the typical spatiotemporal scale of morphological change. From a review of existing literature we propose a consistent definition and present a new classification according to shoreface morphologies,. The lack of a uniform definition of "shoreface", and its variation in meaning for different disciplines (coastal 
engineering, geology, oceanography...) has led to discrepancies in terminology. While this is addressed in the next section of the review, from this point on we refer to the shoreface as the transitional zone between shelf and beach, delimited on the shoreward limited shore side by the (fairweather) surf zone (or swash zone) and seaward by the threshold beyond which sediment transport is no longer intense enough to contribute to the overall coastal dynamics at a mesoscale (time scale of $10^{1}$ to $10^{2}$ years and a spatial scale of $10^{1}$ to $10^{2} \mathrm{~km}$ ). However the shoreface exhibits changes at other spatiotemporal scale, this will be explicated below.

\section{Definition of the shoreface}

The shoreface can be loosely defined as the transition zone between the beach and the shelf (Figure 1). Definitions of its shoreward and seaward limits and internal subdivision are still not fully agreed upon. Some authors (Ortiz and Ashton, 2016; Thieler et al., 2001, 1995) suggest the subaerial coastal zone itself represents the shoreward boundary, thus including the surf zone (Niedoroda et al., 1984) or the lower limit of the swash (Aagaard et al., 2013). Others (Backstrom et al., 2007; Héquette and Hill, 1993; Héquette et al., 2001; Wright et al., 1991, 1991) place the landward boundary between the shoreface and the surf zone. Green et al. (2004) refer specifically to the 'breakpoint' as the landward limit of the shoreface. On beaches without surf zones e.g. Caribbean beaches (Boon and Green, 1988), the shoreface might extend landward to the beach step and swash zone. 


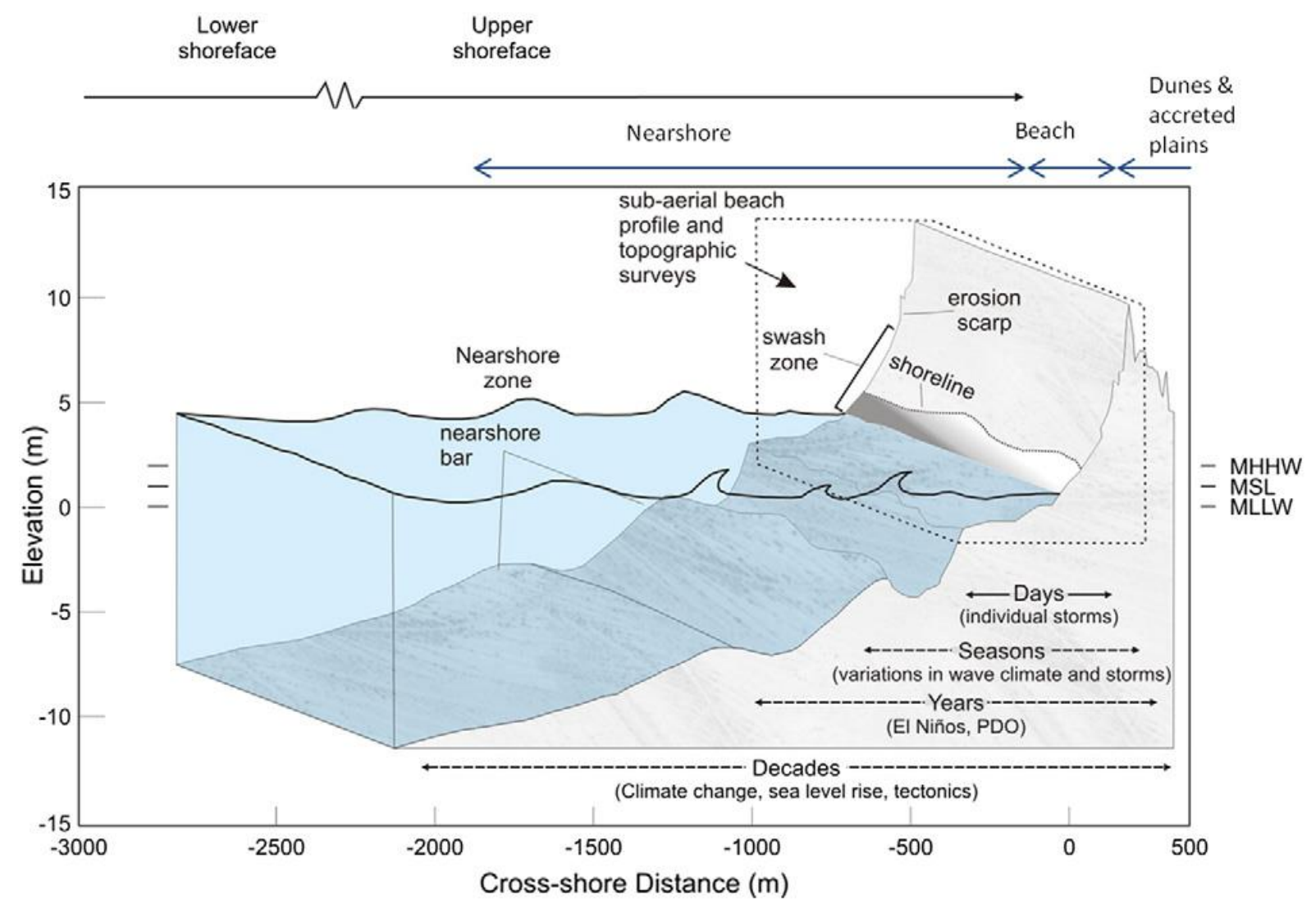

Figure 1. (colour) Conceptual diagram of the current definition and limits of the shoreface (from Ruggiero et al. (2016))

The seaward limit is equally contentious due largely to the fact that it is often hard to identify a definitive morphological feature (e.g. a break in slope) or change in texture between the shoreface and the continental shelf. Without a physical reference location the spatially and temporally variable point at which waves start to mobilise sediment (i.e.in other words the wave base where waves begin to interact with the sea bed sediment) is normally used (Aagaard, 2014; Dashtgard et al., 2012; Stive and De Vriend, 1995). Wave base is temporally variable and hence a definition of the timescale for assessment of wave base is required (see section 4.).

The shoreface can also be defined in terms of the physical processes that occur within it. Héquette et al. (2008a, p. 227) proposed that the shoreface is 'the shallow, friction-dominated zone where the response of the seabed to hydro-meteorological forcing results from the complex interactions between wind, waves and currents'. In this process-based approach, the shoreface comprises two sections: the upper shoreface which is influenced by wave-breaking processes and the dissipation of 
wave energy (i.e. the surf zone in other definitions) and the lower shoreface that is dominated by wave shoaling (Aagaard, 2014; Stive and De Vriend, 1995). The shoreface is a wave-affected zone (Swift et al., 1985; Wright et al., 1991), even at its seaward, deepest point. Incoming waves impact the bottom from a starting point commonly defined as the wave base until they reach the shore. This definition is similar to the profile zonation proposed by Hallermeier (1981) that introduced potentially calculable depths for the boundaries between upper and lower shoreface and between lower shoreface and shelf (Cowell et al., 1999) based on wave parameters. In this definition, the upper shoreface is the zone most likely to experience strong seasonal variability and is therefore equivalent to the shoreface 'active zone' as defined by Stive and De Vriend (1995), with its seaward boundary being the depth of closure as calculated using Hallermeier (1978) formula. In this zonation, the lower shoreface is bounded seaward by the calculated maximum water depth for initiation of motion (wave base) under annual median wave conditions. However, the depth of closure and maximum depth for waveinitiated motion are temporally variable parameters and cannot be considered an absolute calculable boundary for the shoreface.

Other authors have proposed discriminating the shoreface according to slope (Swift et al., 1985) or sediment type and characteristics (Aragonés et al., 2018; Cowell et al., 1999; George and Hill, 2008). Larson et al. (1999) examined the theoretical profile under breaking (surf zone, upper shoreface) and non-breaking (shoaling wave condition, lower shoreface) and determined that the 'equilibrium profile' (see section 3) of the lower shoreface is for that instance distinguished from the upper shoreface by a lower curvature than the one of the upper shoreface. Indeed, the separation between upper and lower shoreface zones is sometime set at a discernible break in slope (Niedoroda et al., 1984).

In general use, the term 'shoreface', when not more fully specified, appears to refer to the lower shoreface, as most authors equate it with an environment dominated by wave shoaling that is active only at a long time scale, i.e decades and longer(Aagaard, 2014; Green et al., 2004; Héquette et al., 2008a; Niedoroda et al., 1984). In current usage, the 'upper shoreface' therefore corresponds to a 
seasonally active zone that sometimes, but not always, includes the surf zone. Typically, the upper shoreface is the zone influenced by the offshore migration of the surf zone during storm conditions that results in morphological changes at a seasonal time scale. This inconsistency in terminology regarding the shoreface can be confusing Subsequently, we propose a standard definition.

\section{Shoreface equilibrium profile}

Most models of beach/shoreface profiles are based on the assumption of the existence of an equilibrium profile. The equilibrium profile in the literature has its origins as far back as Fenneman (1902, p. 1) who wrote: "There is a profile of equilibrium which the water would ultimately impart, if allowed to carry its work to completion". This concept is still widespread in coastal evolution models, especially in engineering applications (Cooper and Pilkey, 2004).

The profile of equilibrium can be defined as the theoretical, two-dimensional shape achieved by a sand-rich, unconstrained coastal system under a given stable wave climate and sediment type. These are the conditions of flume tank experiments that were first used to explore the concept of equilibrium profile (Dean, 1991). In theory, when the system is in equilibrium then no net sand transport occurs and the rate of dissipation is constant. It is the result of an equilibrium between onshore directed (constructive) sediment transport and offshore (destructive) sediment flow and is usually concave upward as described by Dean (1991). Its form is described by an empirical equation of the form:

$$
h(y)=A y^{n}
$$

where: $h(y)$ is the water depth $h$ at distance offshore $y, A$ is a scale parameter (dependent on grain size) and ' $n$ ' is a parameter commonly set at $2 / 3$ (the best fit to field data found by (Dean, 1977))

(Figure 2). The profile of equilibrium of a coastal system can also be obtained from field data by analysing a time series of cross-shore profiles (Birkemeier, 1985; Hinton and Nicholls, 1999; Nicholls et al., 1998; Różyński et al., 1999). 


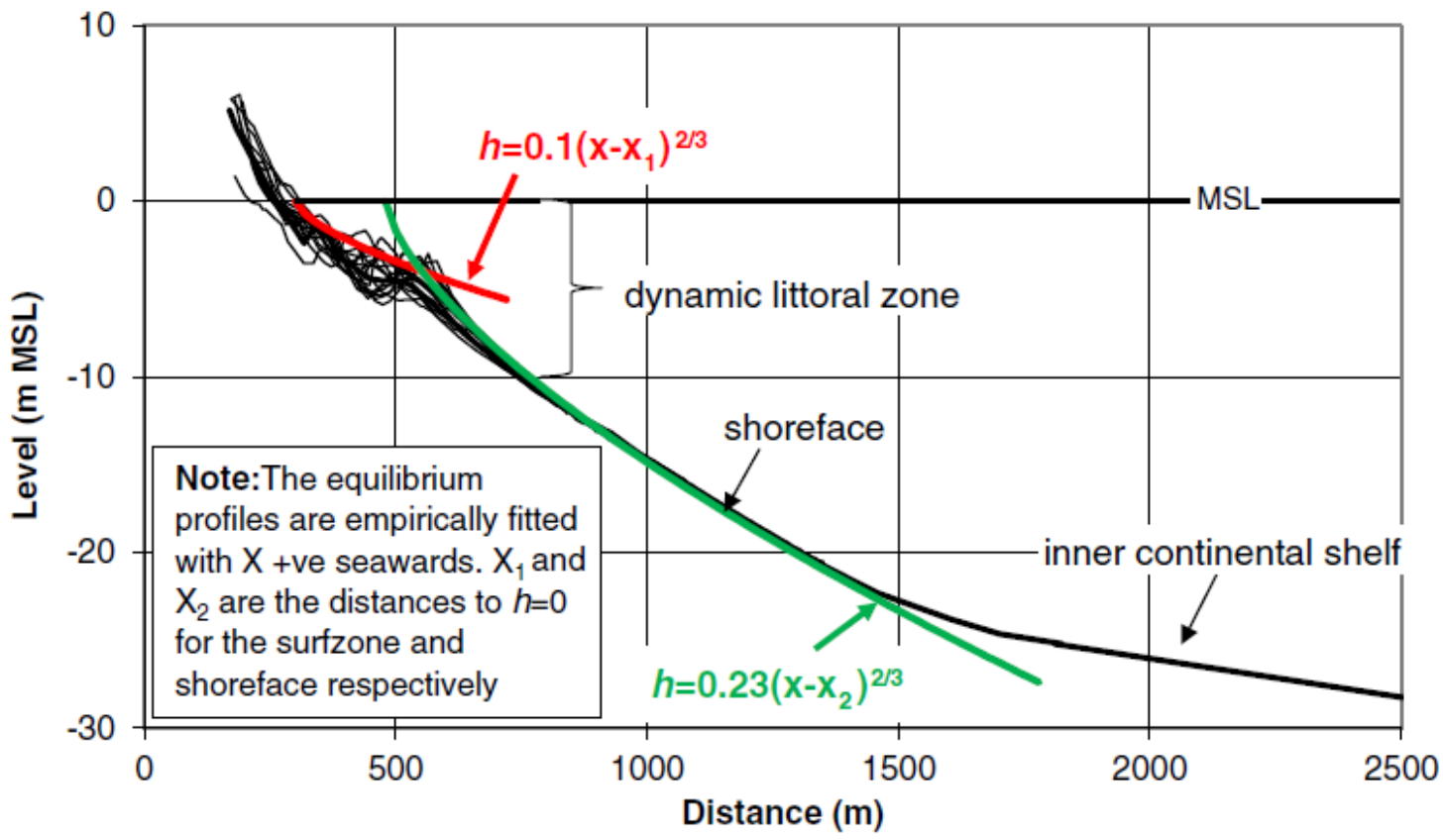

158

Figure 2. (colour) Example of equilibrium profiles fitted for the surf zone and shoreface on the Australian Gold Coast (from: Patterson and Nielsen 2016). In this example, the dynamic littoral zone equates to the surf zone and upper shoreface.

Pilkey et al. (1993) reviewed the principle of equilibrium profile and demonstrated that the conditions (i.e. a sand-rich system not affected by transient sand bodies or underlying geology and closed by an offshore boundary) that are required for an equilibrium are unrealistic assumptions in a natural environment. Pilkey et al. (1993) also pointed out that the equilibrium equation is flawed because the only variable influencing the shape of the profile is the grain size (expressed as $A$ ) and the wave climate and inherited morphology have no influence. Similarly, Thieler et al. (1995), pointed out the inconsistent grain size across the shoreface which cannot be accounted for by a single number ( $A$ in Dean's equation). They also showed that the apparent relationship between ' $A$ ' and grainsize is not evident when only sand grain sizes are considered. Those authors also demonstrated the major control played by underlying geology on shoreface morphology.

Backstrom et al. (2007) showed from field measurements that adjacent shorefaces could have markedly different shapes that diverged from potential 'equilibrium' profiles. While one of the sites displayed a concave-up type morphology closer to 'typical equilibrium profile' the other had a linear to convex profile. The presence of other convex morphologies on shorefaces worldwide (Aleman et 

equilibrium profile morphology as a universal principle, as do shorefaces whose morphologies are influenced by rock outcrop and sub-crop (Browder and McNinch, 2006; Riggs et al., 1995; Thieler et al., 1995).

While the principle of equilibrium is a valid concept to describe the evolution of an idealized coastal system, it appears to have limited applicability for "real-world" situations (Athanasiou et al., 2019; Pilkey et al., 1993; Thieler et al., 1995). This is mostly because the forces that affect morphology and drive morphological change on the shoreface appear to be controlled, at least in part, by factors other than waves and grain size. Clifton (2005), states that for a transgressive shoreface profile (which make up the majority of the world's coasts (Bird, 1985)) only the upper part is "wave-tuned" and theoretically able to attain equilibrium, while the lower part of the profile is shaped by differential erosion due to the presence of older deposits.

Extensive research has been conducted on the "active" part of the profile and its influence on shoreline and beach dynamics. This is particularly pertinent when considering seasonal variation, event scale (storm) dynamics and shoreline variability. Most coastal evolution models also focus on this zone because the lower part of the shoreface lies beyond the "depth of closure" and its dynamics are considered to only be significant during storm events when sand is 'lost' (i.e. transported from the upper shoreface to the lower shoreface) (Cowell et al., 1995; Stive and De Vriend, 1995).

While the shoreface has mostly been considered two-dimensionally, it has become more evident that longshore variations often exist and that many shorefaces are strongly three-dimensional. This is related to the presence of various sedimentary features (see section 7) and/or the influence of the geological framework (see section 6).

\section{Depth of closure and the shoreface}


The depth of closure commonly refers to the seaward limit at which morphological change is not observable for a (usually seasonal) period of time; it also commonly is regarded as the boundary between upper and lower shoreface (Cowell et al., 1999)

The depth of closure can be determined by analysing a time series of profiles at a given location (Różyński et al., 1999) or consecutive bathymetry datasets (Robertson et al., 2007) to identify the depth at which the change in morphology becomes insignificant (not measurable), keeping in mind that the depth of closure is related to the time-scale of the measurements and to the measurement accuracy (Hoekstra et al., 1999). Various statistical methods also exist to identify this threshold (Kraus and Harikai, 1983; Nicholls et al., 1997). However, most commonly, and because datasets necessary to determine the depth of closure are relatively rare, the DoC is usually calculated from wave parameters.

Depth of closure calculations were introduced by Hallermeier $(1981,1978)$. Hallermeier's DoC calculation is based on the wave period and height and determines the closure depth $(d l)$ for an annual wave return period.

$$
d I=2.28 H s-68.5\left(\frac{H s^{2}}{g T s^{2}}\right)
$$

With $\mathrm{Hs}$ the local significant wave height and $T s$ the significant wave period.

Related to depth of closure is the wave base, referred to by Hallermeier (1981) as the outer depth of closure (di) (as opposed to the DoC which is referred to as the inner depth of closure $(d l)$ ) (Figure 3 ). The outer DoC was defined as "maximum depth for motion initiation by median wave conditions" by (Hallermeier, 1981) and corresponds to the limit of wave-initiated cross-shore sediment transport, or the seaward limit of the wave-constructed profile. It is defined as the depth at which the incident wave reaching the shore begins to shoal and can be calculated using:

$$
d i=(H s-0.3 \sigma) T s\left(\frac{g}{5000 D}\right)^{0.5}
$$




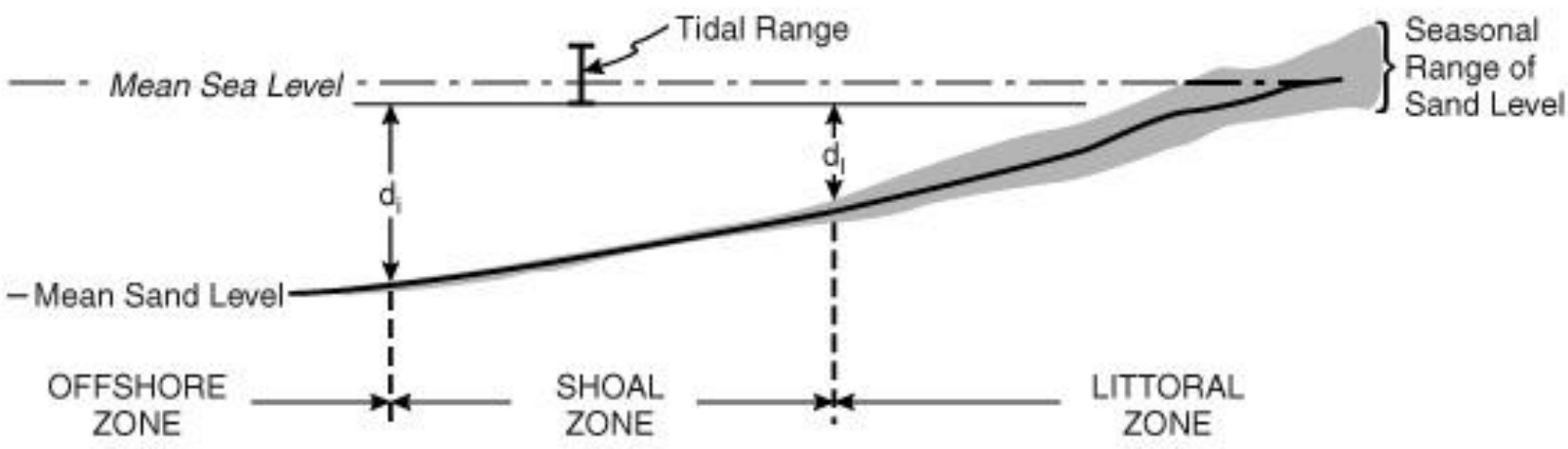

Figure 3. Definition of inner and outer depth of closure (Hallermeier, 1981) with dl the inner depth of closure (DoC) and di the outer depth of closure or wave base. Here, the littoral zone corresponds to the upper shoreface and the lower shoreface is included in the shoal zone.

Subsequent studies (Nicholls et al., 1997) building on the work of Hallermeier $(1981,1978)$ have shown that the depth at which closure is calculated is highly time-variable, and it increases with the timescale involved (Nicholls et al., 1999, 1998). It is therefore customary to associate a depth of closure with a temporal dimension. The DoC can be calculated for a specific event (Robertson et al., 2008), but more commonly it is calculated for yearly/ seasonal variations or even over a number of years (Valiente et al., 2019) up to decades (Hinton and Nicholls, 1999) and even millennia (Ortiz and Ashton, 2016). Similarly, the wave base depth is usually calculated for a typical year. And as with the DoC, it varies with the return period used for the calculation

The depth of closure is also known to be variable in the longshore (Hinton and Nicholls, 1999; Sabatier et al., 2005) with influences exerted by sedimentology and underlying geology (Robertson et al., 2008), as well as wave exposure.

While most of the literature has focused on the depth of closure, recent studies have proposed new calculations for the lower shoreface/ shelf threshold and advanced the definition of the seaward limit of the shoreface. For example. Ortiz and Ashton (2016) introduced the notion of morphodynamic 
depth of closure (MDOC) defined as the depth beyond which 'evolution of the shoreface becomes geologically slow and the bed shape response to environmental change becomes virtually nonexistent'. Ortiz and Aston's (2016) calculated MDOC is dependent on wave height and period but is not affected by the sediment grain size; it only influences the shape of the modelled equilibrium profile. This method of calculation, which proposes a calculation of the depth at which morphological variability is geologically slow (millennia), is relevant to studies of shoreface morphodynamics and more generally to the study of macro-scale (time scale $>10^{1}$ years and spatial scale $>10^{2} \mathrm{~km}$ ) coastal behaviour.

Valiente et al. (2019) used wave bed shear stress to estimate the seaward limit of significant sediment transport (contributing to the overall coastal dynamics). This depth of transport (DoT) outer limit takes into account both wave-induced stress and stress induced by tidal currents. Their approach makes the distinction between DoC which limits the zone of significant morphological change i.e. the upper shoreface (which can be approximated by Hallermeier's formulation) and the DoT that delimits the zone of significant sediment transport. The use of bed shear stress permits identification of the zone where sediment transport is significant in terms of volume but where no morphological changes are observable at the medium term $\left(10^{0}\right.$ to $10^{1}$ years $)$. It is therefore a good potential proxy for the lower shoreface/shelf boundary, as it determines the extent of the active shoreface. In contrast, the wave base (DoC) only encompasses the wave-affected areas of the shelf where significant morphological change is observed.

For the upper/ lower shoreface limit, several methods of DoC identification exist. For example, Aragonés et al. (2018) proposed that DoC could be defined as 'the point where the minimum size of sediment is located'. Aragonés et al. (2019) further proposed a numerical model based on wave parameters and sedimentology to determine the depth of closure. 
applicable especially where rock outcrops or limited sand supply constrain sediment transport on the shoreface. Miselis and McNinch (2006), for example, showed that using calculated depth of closure can cause an over-estimation of the volume of nearshore sediment in geologically (vertically) constrained areas.

\section{Shoreface hydrodynamics}

Waves have an oscillatory motion that is modified by the interaction with seabed as they cross the shoreface. Incoming waves dissipate energy over the shoreface and this may lead to sediment transport and morphological evolution (Roelvink and Stive, 1991). When the critical bottom friction is reached, seabed sediment starts to be transported either as suspension or as bed load, making incoming waves one of the main driving factors for sediment transport in the coastal zone. Over the shoreface, because of diminishing depths, waves shoal before breaking in the surf zone. Shoaling creates an asymmetry in the wave oscillation, resulting in net sediment transport directed toward the shore (Austin et al., 2009; Huisman et al., 2019; Niedoroda and Swift, 1981). This is especially true under fair-weather conditions when wave oscillation asymmetry is the main process driving onshore sediment transport (Niedoroda and Swift, 1981; Niedoroda et al., 1984; Swift et al., 1985). Incoming waves can also create steady currents such as undertow and rip currents, particularly in the surf zone. These are strongly related to morphology and beach slope (Castelle et al., 2016). These flows are directed offshore and tend to transport sediment from the surf zone to the shoreface, particularly during high-energy storm conditions (Loureiro et al., 2012a). The importance of infragravity waves on cross-shore sediment transport is still unclear (Bakker et al., 2016; Bertin et al., 2018) but it has been hypothesised that they can contribute to offshore transport during storms (Russell, 1993).

Another factor influencing sediment transport in the coastal zone is wind. Currents generated by winds can be drivers of sediment transport, especially down-welling currents that, during storms, have the capacity to move sediment offshore (Héquette and Hill, 1993; Héquette et al., 2001; Niedoroda et 
al., 1984). Swift et al. (1985) pointed out the importance of wind-driven coastal flow for the sediment budget, especially when intensified by storms, stating (p. 332) that "Because of the offshore component of bottom flow, sand is swept down the lower shoreface and onto the adjacent shelf. Fair weather processes may be unable to return storm-deposited sand to the beach from such an offshore position".

Wind forcing may also affect the tidal current velocity by reinforcing or limiting it depending on the concordance of wind and current direction (Héquette et al., 2008a). It also causes near-bottom currents which affect sand ridge migration (Guerrero et al., 2018) (see below in section 7).

Tidal currents can also be a significant component in sediment transport on shorefaces. On microtidal shorefaces, tidal currents are generally overlooked. Moreover, since tidal currents are often symmetrical their significance can be limited when averaged over a tidal cycle (Niedoroda et al., 1984). On shorefaces where morphology creates tidal asymmetry, however, sediment transport from residual tidal currents is non-negligible whereas, in meso- and macrotidal environments, tidal currents are fundamental in driving sediment transport (King et al., 2019; Valiente et al., 2019). In their study of sediment transport on a tide dominated (macrotidal) shoreface environment, Héquette et al. (2008a) found that, although waves were the main forcing parameter in mobilising sediment as they cross the shoreface, sediment transport vectors were linked to average currents directed alongshore, in particular, tidal currents.

Hydrodynamics on the shoreface potentially involve a combination of wave, wind and tidal current action. These processes can interact via positive or negative feedback. For example, winds can play a role in enhancing or inhibiting tidal currents depending on the relative direction of both those forces (Héquette et al., 2008b). During storm wave events, the combined action of waves and winds tends to create offshore-directed currents that move sediment to the lower parts of the shoreface and shelf (Héquette et al., 2001; Niedoroda and Swift, 1981; Wright et al., 1991) whereas, under fair weather conditions, smaller waves tend to move sediment onshore (Wright et al., 1991). As most mean 
currents (i.e. rip currents, undertow, down-welling) are directed seaward, onshore sediment transport only occurs under favourable conditions for a limited time. Wright et al. (1991, p. 46) found that at Duck beach (North Carolina, USA), storms were "capable of transporting more sand offshore in an hour than fairweather processes can move onshore in two or more days".

Over longer time scales $\left(10^{0}\right.$ to $10^{1}$ years), the variability in shoreface morphology may be influenced by climatic factors such as ocean circulation patterns or oscillation. In particular, El Niño/ La Niña periods have been shown to have specific impacts (shift in sediment transport and morphological responses) on the coast and shoreface (Goodwin et al., 2013; Ruggiero et al., 2005; Wright et al., 1991). Other factors such as storm grouping (Lee et al., 1998; Loureiro et al., 2012b) also exert a control on shoreface dynamics. Indeed, a series of storms often has a more extreme effect than a single (even more energetic) storm in creating morphological changes and causing erosion of the Jackson, 2019, 2018).

\section{Geological influences on the shoreface}

It has been shown that underlying geology is a limiting factor for the formation of equilibrium profiles (Pilkey et al., 1993), and various studies have emphasised the role of geology and coastal morphology on mesoscale coastal behaviour(Cooper et al., 2018; Gallop et al., 2020; Jackson et al., 2005). A large proportion of the world's coast is rocky and/or embayed (laterally constrained) and there is much variability in sediment volume and thickness. The potential for erosion of the underlying lithology to produce shoreface sediment is also highly dependent on lithology and dynamics as well as the rate of sea-level rise.

Coasts can acquire equilibrium profiles if the shoreface is sand-rich and the underlying and offshore geology does not play any part (Pilkey et al., 1993). These conditions are unrealistic for most of the 
341 world's shorefaces. Typically, for the barrier island coast of North Carolina, for example, Pilkey et al.

342 (1993, p. 271) found that 'the shape of the shoreface in sediment-poor areas is determined by a complex interaction between underlying geology, modern sand cover and highly variable incoming wave climate'.

Other studies on North America's Atlantic coast confirm this observation. Riggs et al. (1995) showed that the geological framework determines 3D shoreface morphology, sediment texture and composition as well as shoreline recession rates, concluding ( $\mathrm{p}$ 231) that 'each barrier beach and shoreface are total products of their geologic heritage; the signature of their history controls and influences the present morphology, shoreface dynamics, and rates of shoreline recession'. Thieler et al. (1995) examined the variation in grain size, underlying geology and sediment transport of Wrightsville Beach (North Carolina) and found a lack of homogeneity in sediment distribution and irregular bathymetry that also indicated a strong control by underlying geology on sediment transport processes on the shoreface.

The geological framework can influence both the volume of sediment available for transport but it can also in some region impede sediment transport reducing the amount of sediment contributing to a coastal system's sediment budget (Menier et al., 2019, 2016). Furthermore, the geological setting of the shoreface and the volume of shoreface sediment readily available for transport seem to have an influence on shoreline evolution pattern (see section 8.3).

For most coasts influenced by their geological setting, conventional theories of shoreface morphodynamics are inadequate. Indeed, in geologically constrained areas it has become evident that commonly accepted theory related to nearshore morphodynamics, such as equilibrium profiles (Pilkey et al., 1993; Riggs et al., 1995; Thieler et al., 1995), depth of closure (Robertson et al., 2008, 2007), or beach state parameters (Jackson et al., 2005; Loureiro et al., 2013) are not directly applicable. 


\section{Sedimentary Bedforms}

Sedimentary bedforms on the shoreface occur at various length scales from ripples $(\mathrm{cm})$ to fields of multi-metric sediment-rich features known as sand ridges $(\mathrm{km})$, they are the result of complex hydrodynamics, including feedbacks between the seabed and tides/currents. Their formational mechanisms and self-organisational processes are still unclear (Durán et al., 2018; Guerrero et al., 2018; Murray et al., 2014b; Nnafie et al., 2015, 2014). In terms of shoreface dynamics, sedimentary bedforms can act as possible sources/sinks of sediment and can also influence sediment characteristics (sorting etc.) and nearshore hydrodynamics (via change bathymetry, bottom roughness etc.) (Latapy et al., 2020; Verwaest et al., 2020).

The main sedimentary features present on shorefaces are sand ridges (Madricardo and Rizzetto, 2018) . On macro-tidal coasts, sand ridges are mostly related to tidal hydrodynamics. They are termed tidal sand ridges or tidal sand banks or waves. They originate from the hydrodynamic climate created by strong tide-related currents, as stated by Anthony (2013, p. 10); “In the course of the Holocene, [...] sand has been reworked by the interplay of tidal currents and storm waves into the impressive jumble of tidal sand ridges and banks that have served as sources for coastal accretion." Tidal sand banks are usually sub-parallel to the shoreline and attuned to the local tidal current climate. They exist on the shoreface and can migrate onshore under storm conditions at the rate of several metres per year (Héquette and Aernouts, 2010; Héquette et al., 2013; Van der Molen and Van Dijck, 2000).

Sand ridges also exist on coasts where they are not the product of tidal hydrodynamics. In such cases they are referred to as sand ridges, shoreface-attached sand ridges, or shoreface-connected ridges (SCRs) (Figure 4). SCRs are shoreline-oblique, rhythmic sand ridges. The spacing between each ridge is in the 1-10 km order, their height can exceed $10 \mathrm{~m}$ and their length more than $25 \mathrm{~km}$. Found at depths of 5-20 m with their landward end connected to the shoreface (hence the name), they often develop at an angle of around $20^{\circ}$ to the shoreline. They occur particularly on storm-influenced shelves and 
can migrate with the dominant current at a rate of several meters per year (Calvete et al., 2001a, 2001b; Falques et al., 1999; van de Meene and van Rijn, 2000a, 2000b; Yoshikawa and Nemoto, 2014).

The formation processes of SCRs are rather unclear. Some suggest they are pre-Holocene transgression relics (McBride and Moslow, 1991) while others have focused on the physical processes necessary to create and sustain such bedforms (Calvete et al., 2001a, 2001b; Trowbridge, 1995; VisStar et al., 2007). Their dynamics are complex (Browder and McNinch, 2006; Falques et al., 1999; Goff et al., 2015; Guerrero et al., 2018; McNinch, 2004; Schupp et al., 2006) and many are assumed to have formed at shallower depth and been subsequently drowned by rising sea level (Durán et al., 2018; Nnafie et al., 2015, 2014).

Other shoreface features have been termed sorted bedforms or rippled scour depressions (RSDs)

(Figure 4). These are relatively stable features that have been widely documented. RSDs comprise alternating sand and coarse gravel bands with shore-oblique to shore-normal orientation. The coarse gravel is commonly rippled, while the surrounding sand is fine and featureless. Their significance, formation and dynamics are still discussed (Liu et al., 2018; Mielck et al., 2015; Murray et al., 2014a; Rosenberger et al., 2019). Some have been attributed to channelized offshore storm-return flows (Pretorius et al., 2018) and they are thought to exhibit positive sorting feedback (Goff et al., 2005; Green et al., 2004; Gutierrez et al., 2005; Murray and Thieler, 2004). Other smaller sediment structures or sediment heterogeneities have also been described on the shoreface, such as ripples or gravel outcrops (Browder and McNinch, 2006; Inman and Adams, 2005; Schupp et al., 2006). 


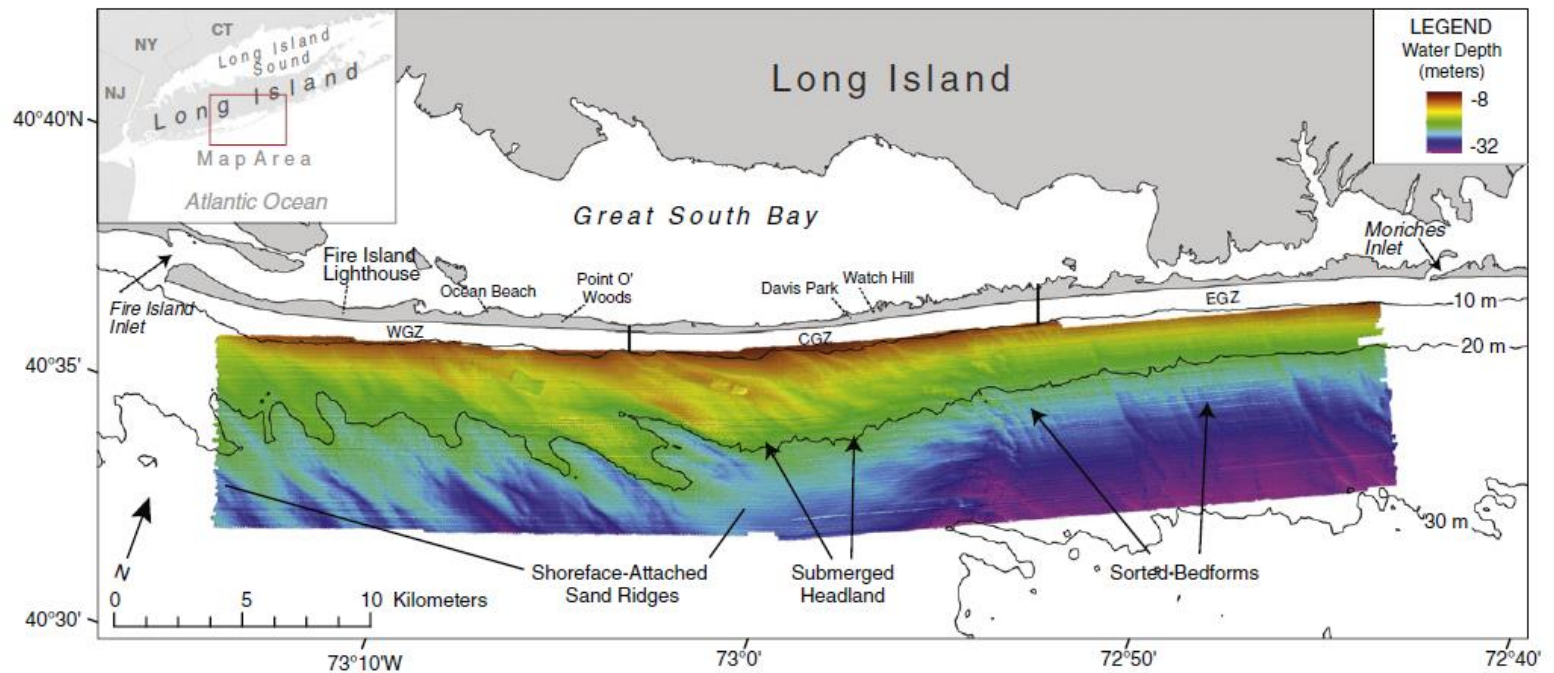

Figure 4. (colour) Example of sedimentary bedforms (shoreface-connected ridges \& sorted bedforms) visible on the

412 In some instances, formation and evolution of superficial sand bodies is linked to the geological

413 framework. For example, McNinch (2004) and Browder and McNinch (2006) found a correlation between the presence of palaeochannels and shore oblique sandbars. They postulated that inhomogeneity in the geological framework could influence the hydrodynamics and that variation in the nature of the outcropping seafloor could influence the organisation of bedforms. Similarly, Durán et al. (2018) postulate that irregularities in palaeotopography initiate the formation of and influence the orientation and distribution of sand ridges.

The sedimentary features present on the shoreface can be an indication of the sediment supply available. Thieler et al. (2014, p. 128) state that 'where modern sediment is relatively abundant, the inner shelf contains shoreface-attached ridges and shoal complexes. Where modern sediment is lacking, the seafloor is characterized by sorted bedforms'. Bedforms and sand bodies, as they develop and evolve under a specific set of conditions, are morphological indicators of the physical environment on the shoreface, such as the hydrodynamic climate or the sediment availability. More importantly, sedimentary features present on the shoreface also seem to influence coastal morphodynamics and shoreline evolution in many ways (see section 8.3). 


\section{Shoreface morphodynamics}

\subsection{Shoreface zonation: Upper/Lower shoreface}

430

431

The division between upper and lower shoreface morphodynamics is reflected in the notion of depth of closure (and associated wave base) as described by Hallermeier (1981). A number of studies on depth of closure exist in the literature (Birkemeier, 1985; Li et al., 2005; Nicholls et al., 1998, 1997; Robertson et al., 2008), and a selection of studies in contrasting environments are reviewed here.

Within a micro-meso tidal environment on the Dutch coast where mean tidal range varied from $1.4 \mathrm{~m}$ to $1.7 \mathrm{~m}$ and peak tidal velocity reached $1 \mathrm{~ms}^{-1}$, Hinton and Nicholls (1999) analysed a long-term dataset (20 years) of shoreface profiles to identify the depth of closure for various sections. The observed DoC ranged between 5.0 and 9.2m. Hallermeier's DoC (using a 5-year period) was also calculated, and predicted a DoC at 9.2m. Hinton and Nicholls (1999), however, also observed significant morphological variation seaward of this depth of closure. This morphological variability was only observed over longer time scales $\left(>10^{1}\right.$ years) and at depths greater than $12 \mathrm{~m}$. This suggested that the shoreface displays two distinct behaviours occurring at different time scales, highlighting the different behaviour of the upper and lower shoreface zones.

In the Mediterranean Sea, a low-energy micro tidal environment, Frihy et al. (2008) examined the seasonal response of the Abu Qir Bay, Egypt, calculating monthy DoC (using Hallereier's formula) and depths of wave base. While the DoC $(d l)$ varied between 6 and $14 \mathrm{~m}$ the wave base $(d i)$ varied between 16 and $29 \mathrm{~m}$. Maximum di varied between $45 \mathrm{~m}$ in winter and $23 \mathrm{~m}$ in summer. A previous study (Naffaa et al., 1995) of the DoC that encompassed the same area calculated observed DoC (using historical survey map data) as well as Hallermeier's $d l$ and $d i$. The observed DoC calculated for over 65 years was $25 \mathrm{~m}$. Naffaa et al. (1995) calculated the di with the same 65 years return period and obtained a value of 25.7m using Hallermeier's equation. The Frihy et al. (2008) study of Abu Qir Bay showed seasonal patterns attuned to the wave climate and in particular to the fair/storm weather alternation and, for 
the same area the work of Naffaa et al. (1995) showed, that the lower shoreface was morphologically active on a multi-decadal time scale $\left(>10^{1}\right.$ years $)$.

454

455

Valiente et al. $(2019,2017)$ calculated the inner and outer depths of closure, according to various formulations, for the macrotidal, high energy embayments of the coast of Cornwall and Devon (UK) using a 4-year wave time series, giving results ranging between $18.8 \mathrm{~m}$ and $23.3 \mathrm{~m}$ for $d l$ and between $33.6 \mathrm{~m}$ and $50.1 \mathrm{~m}$ for $d i$. Both $d i$ and $d l$ decreased from south to north according to the decrease in incoming wave heights. Using nearshore wave conditions obtained through hydrodynamic modelling, Valiente et al. (2019) also looked at spatial variability of the DoC within each embayment as well as the average DoC for each embayment. When compared to observed DoC (obtained from repeated shoreface profiles over a 6-year period at one of the embayment), they found that offshore wave conditions over-estimated the $\mathrm{DoC}$ and that the use of wave conditions at the $20 \mathrm{~m}$ contour returned results more comparable to the observed DoC. Overall their results showed that Hallermeier's DoC (calculated with nearshore wave climate) remains a valid approximation for the identification of the limit of significant seasonal morphological change. They also looked at bed shear stress as an indicator of the boundary for sand motion (DoT, depth of transport; see section 4) and when taking tides into account DoT reaches 30 to $50 \mathrm{~m}$ for macrotidal Cornwall. This showed that intense sediment transport occurs deeper than previously considered (especially in macrotidal environments) meaning that the volume of reworked and transported sediment on the lower shoreface is most likely to be larger than previously thought and is certainly non-negligible.

While both upper and lower shoreface zones are active, it appears that the time scales at which morphological change operates in each zone are significantly different. Further, even if the upper shoreface dynamic is closely linked to nearshore wave conditions, both upper and lower shoreface morphodynamics are the result of the combined effect of multiple drivers and interactions that modify the net shape of the shoreface across different temporal scales. 
478 Morphological change on the lower shoreface is driven by the effect of waves and currents combined, with most variability occurring during storm events when currents tend to transport sediment from the foreshore/upper shoreface onto the lower shoreface (Niedoroda and Swift, 1981; Niedoroda et al., 1984; Swift et al., 1985; Vincent et al., 1983). As morphological variability on the lower shoreface is relatively small compared to the upper shoreface it is only observable during energetic events or over longer ( $>10^{1}$ years) time periods. The relative importance of each of the drivers impacting lower shoreface morphodynamics is still relatively unknown. For example, Backstrom et al. $(2015 ; 2000)$ found different morphological responses to a storm on two adjacent shorefaces on the high energy coast of Northern Ireland despite the storm characteristics being similar for both shorefaces. The difference in response of the two shoreface (accretion was observable on one shoreface whilst only minor changes on the other) was attributed to geological shoreface characteristics such as antecedent morphology, slope and the presence of available sediment (sand bodies). Indeed, for the same event the more dissipative shoreface was only slightly affected while the steeper shoreface, with nearby sand bodies, was significantly more accreted.

From the limited set of observations available in the literature, it seems that lower shoreface morphodynamics are influenced both by the hydrodynamic climate and geological factors (i.e. underlying geological framework, sediment supply) reflected in its morphology (Figure 5). The relative importance of internal (hydrodynamics) versus external constraints seems to be variable and dependant on the time scale involved, for example external constraints vary with seasonal or interannual patterns.

There is also marked spatial variability in shoreface morphology and factors such as slope (Aagaard, 2014; Bowen, 1980) influence their behaviour. Patterson and Nielsen (2016) examined sand transport on the lower shoreface in the Gold Coast region of western Australia. The site encompassed the sediment-rich lobe of the Nerang River, as well as adjacent shorefaces which are less affected by the 

local sediment discharge. The long-term evolution (multi-decadal) of the river lobe was interpreted in terms of sediment transport and, as the lobe is in disequilibrium, significant change was observed between 1966 and 2012. Rates of shoreward sand transport from $12.8 \mathrm{~m} 3 / \mathrm{m} / \mathrm{yr}$ at $18 \mathrm{~m}$ to 89.1 $\mathrm{m}^{3} / \mathrm{m} / \mathrm{yr}$ were calculated and shown to be dependent on wave conditions, as well as water depth and shoreface slope.

507 Through numerical modelling, Preston et al. (2018) investigated the role of slope and wave energy in 508 nearshore morphodynamics. They showed that for an embayed beach, shoreface slope exerted a 509 control on beach recovery. Specifically, they suggest that beaches with steeper shorefaces are less 510 likely to recover from storms than beaches with more gently sloping shorefaces because (p.2429) 511 "bathymetric slope is a major control on the nearshore sediment budget under calm climatic conditions". However, during storms, hydrodynamics seem to have more control over sediment loss than the slope (Preston et al., 2018). 

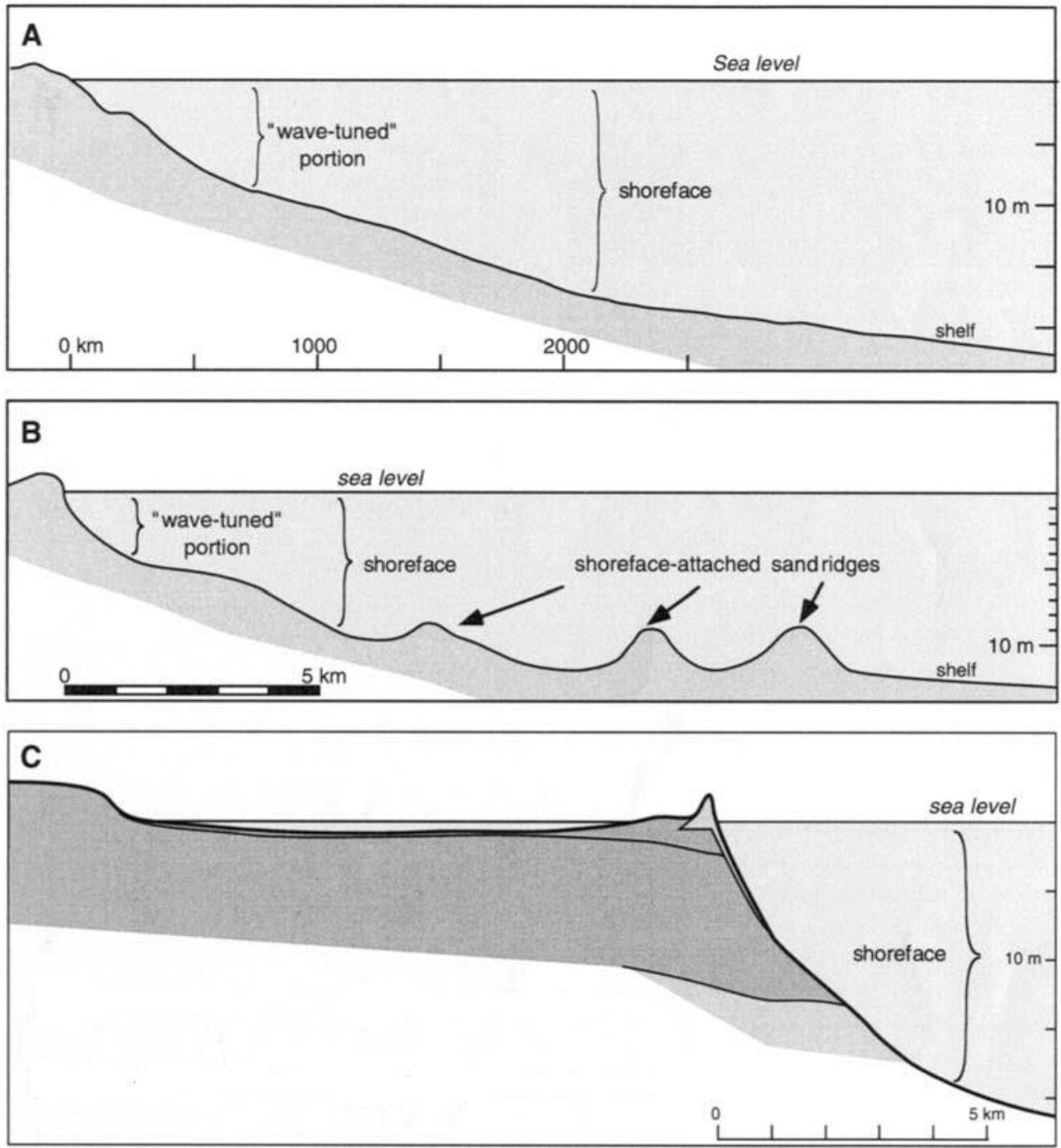

Figure 5. Diagram of various possible shoreface morphologies (Modified from: Clifton et al., 2005) A: Unconstrained morphology B: Morphology influenced by sediment features C: Morphology constrained by geologic framework (thin layer of sand over bedrock)

\subsubsection{Upper shoreface}

519 As a reminder, we propose to define the 'shoreface' as corresponding with the literature definition of the lower shoreface, while the 'nearshore' is defined as a combination of the upper shoreface and surf zone. Although several definitions of the upper shoreface include the (fairweather) surf zone, it is excluded from consideration here since surf-zone processes are distinctive and different (involving wave breaking, secondary wave motions, etc.) Sediment transport on the upper shoreface can be attributed to the temporary extension of the surf zone to the upper shoreface during storm events (Figure 6). Morphological variations of the upper shoreface are thus linked to the dynamics of the outer surfzone bar and the spatio-temporal variability of the position of the surf zone (Lee et al., 1998; 
527 Ruggiero et al., 2016). Antecedent morphology and storm grouping also seem to influence upper 528 shoreface variations. The cumulative effect of successive storms prompts a larger change in upper shoreface morphology because of insufficient recovery between storms.

530 Anthony (2008, p. 243) similarly argued that "Another important aspect of the sediment dynamics of 531 the inner and outer shoreface link is the role of surf zone sediment dynamics in mediating spatial 532 patterns of shoreface elevation change and net losses offshore during storms". In other words, 533 Anthony (2008) suggests that further potential longshore modulation/variation in morphodynamics 534 due to the influence of the surf zone morphodynamics which due to bars and rip effect etc. has a 535 strong three-dimensional component.

536 Aleman et al. (2015) documented the morphological variability of the coast along the Gulf of Lyon 537 (Mediterranean, France). The depth of closure for the area was calculated at $7.6 \mathrm{~m}$ and the DoC 538 observed from successive profile surveys varied between $1.4 \mathrm{~m}$ and $7.4 \mathrm{~m}$ (Sabatier et al., 2005). Here the DoC gives an indication of the extent of the shoreface that is most affected by changes in incoming wave energy, i.e. the upper shoreface. The offshore distance of the DoC put the morphologically active zone (from shore to depth $7.6 \mathrm{~m}$ ) at distances up to $2.5 \mathrm{~km}$ offshore for the more dissipative and rock

542 platform-constrained shoreface profiles. Conversely, for reflective shoreface morphologies, the limit 543 of the active zone was less than $200 \mathrm{~m}$ from the shoreline. This illustrates that a wide array of shoreface 544 configurations can exist for relatively similar offshore wave conditions and tide regimes. It also shows 545 that for different morphologies the extent of the shoreface affected by waves, (the shoaling zone) can vary considerably and with it the stock of sand available for onshore transport. 


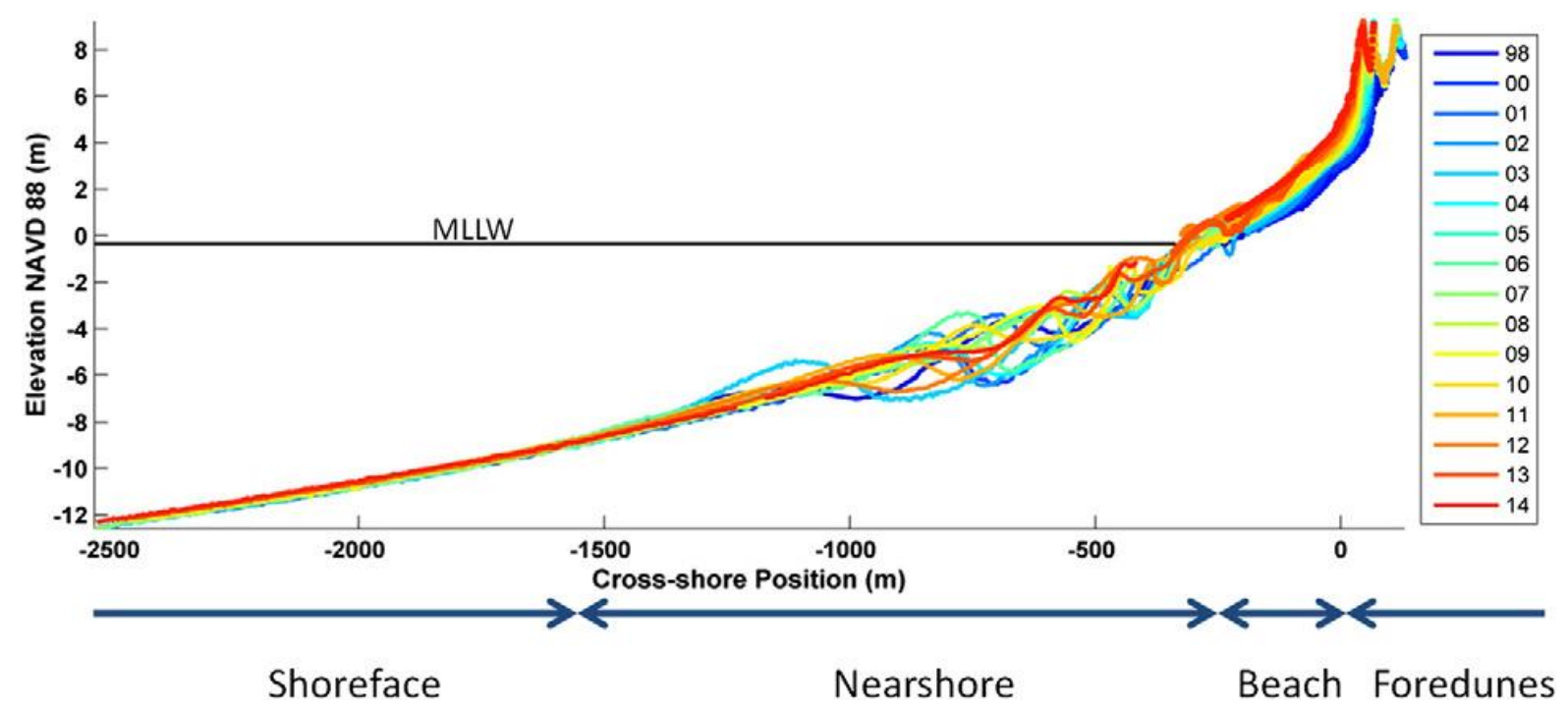

Figure 6. (colour) Example of profile morphological variability in the Long Beach Peninsula (USA) (From: Ruggiero et al 2016). Each profile corresponds to a survey (one per year from 1980 to 2014).

\subsection{3 . Shoreface sediment supply and exchanges}

551

552

Although "long-term observations of shoreface bathymetry change are rare" (Cowell and Kinsela, 2018), sediment transfers to and from the shoreface and within the shoreface itself have been noted in several studies. These transfers have been linked to multiple spatiotemporally variable processes which are primarily episodic in nature (Figure 7). Excluding wave and tide-driven sediment motions (see section 5), the following have been reported:"

1. Variation in surf zone extent. Periodically, under high wave conditions, the upper shoreface is affected by surf zone processes, which lead to appreciable changes in bed level. This is illustrated in the well-known seasonal dynamics of nearshore bars (Aubrey, 1979) and by the seasonal changes in beach/ surf zone states (Wright and Short, 1984; Wright et al., 1985). For example, wave breaking typically occurs further offshore during winter than summer. Indeed large wave events are responsible for transfer of sediment between the shoreface and surfzone/beach. Often this is evidenced in onshore bar migration at seasonal timescales (Aagaard et al., 2010, 2004). Offshore bar migration in the surf zone usually ends with bar disintegration and sediment dispersal at the seaward limit of the surf zone (Shand et al., 1999). 
2. Generation of rip currents. Rip currents that originate in the surf zone can carry sediment offshore and deposit it on the shoreface where it may be sequestered or return shoreward under constructional wave action (Castelle et al., 2016; Loureiro et al., 2012a).

3. Onshore-directed flows during storms. Extreme waves have frequently been documented to transfer shoreface sediment onshore where it is deposited as washover fans (Aagaard and Kroon, 2019). These sediments originate in the surf zone and sites to seaward, including the shoreface (Schwartz, 1975). Recent studies (Pham et al., 2017) also show that some tsunamigenerated overwash sediments originated from shallow marine (shoreface) environments. from deep water to the shoreface during and after a 1:1000-year storm in the North Sea. Subsequent emergence led to generation of ephemeral spits and barrier islands.

4. Offshore-directed flows. Following storms (Pretorius et al., 2018; Siringan and Anderson, 1994) and tsunami (Richmond et al., 2011; Slootman et al., 2018) deposition of sediment has been recorded on the shoreface. Liu and Goff (2018) documented lobe structures on the stable (prograding) shoreface of Fire Island (New York, USA) that were attributed to storm return flows. Channelized storm return flows have been linked to the formation and maintenance of SCRs (Pretorius et al., 2018).

5. Longshore sediment movement on the shoreface has recently been documented after storm events, both for sand-rich features and sorted bedforms. For example, on Fire Island's shoreface a retreating area showed erosion and subsequent redistribution of sediment via longshore processes (bedforms migration) while nearby sediment rich areas with SCRs also showed signs of longshore sediment transport (Liu and Goff, 2018). Other studies in the same area also documented bedform migration driven by hurricane events (Goff et al., 2015; Schwab et al., 2017). 
6. Shoreface erosion. Evidence of shoreface-derived sediment in the coastal system is widespread, especially on transgressive shorefaces where underlying rock is periodically exposed and subject to wave erosion (ravinement) (Riggs et al., 1995). Contemporary erosion of bedrock outcrop on the shoreface has recently been documented by repeat side-scan sonar surveys in the Baltic Sea (Schwarzer et al., 2014). This sediment contributes locally to the shoreface sediment budget.

7. Shoreface nourishment. Experiments with shoreface nourishment have shown that sediment is exchanged between shoreface and surf zone (Grunnet and Ruessink, 2005; Ojeda et al., 2008), but also that the change in morphology created by nourishments in the form of a bar on the shoreface has a shielding effect during energetic conditions (Barnard et al., 2009; Huisman et al., 2019).

601 


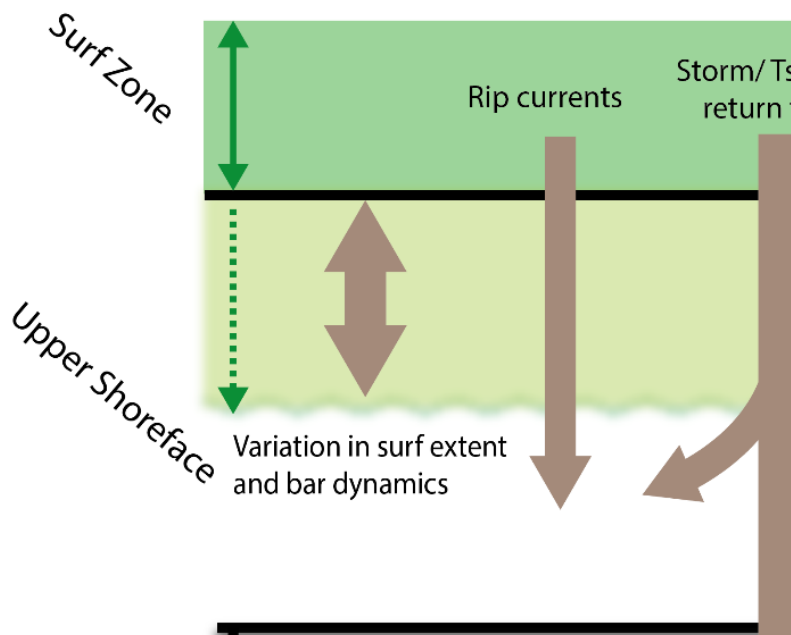
Storm/Tsunami urn flow

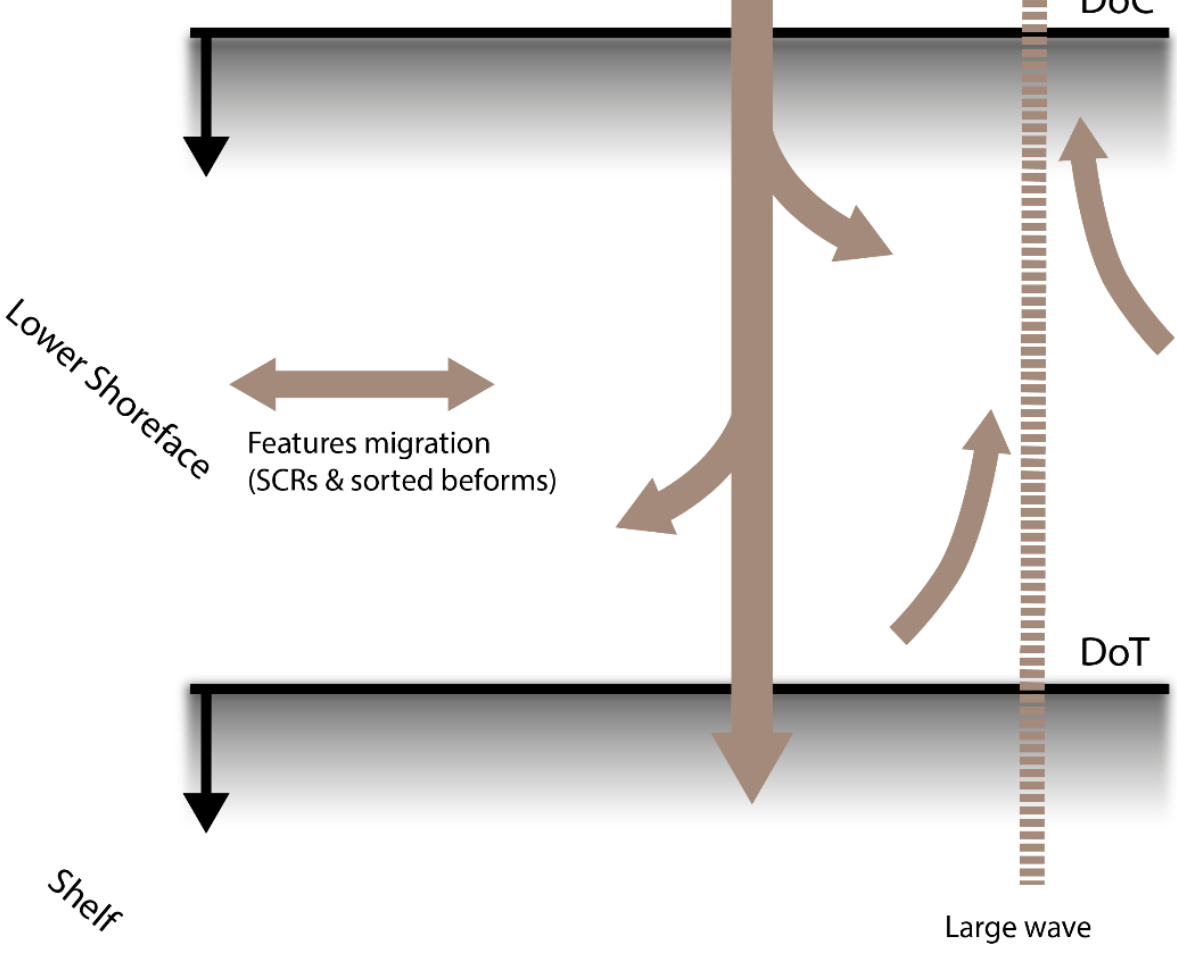

Figure 7: Schematic representation of sediment exchange over the shoreface. With, The surf zone (in dark green) and upper shoreface (light green) are depicted with the upper and lower shoreface limits (solid black lines; see Figure 9) The schematic represents episodic expansion of the surf zone during energetic events. In brown, the arrows depict the sediment transport mechanisms across the shoreface.

\subsubsection{Sea Level Rise}

Understanding the response of shoreface morphology and behaviour to sea-level change over decadal to century timescales ( $10^{1}$ to $10^{2}$ years) is hampered by the lack of long-term datasets and the difficulty of isolating the sea-level signature from that of shorter-term dynamic processes, a problem that persists even on the much more data-rich beach environments (Cooper and Pilkey, 2004). Information about mesoscale shoreface behaviour is, however, sometimes available from discontinuous historical 

(geological, $>10^{2}$ years) time scales, seismic and coring data. The dynamics have also been simulated (and sometimes predicted) via models. A wide array of behaviour models has been developed, from statistical- to process-based models that describe shoreface reaction to sea level rise. Early approaches to long-term shoreface evolution assumed time-invariant shoreface profiles (Cowell et al., 1999), while later models allowed for shoreface profile evolution according to the presence of an erodible or non-erodible substrate (Thieler et al., 1995). Some of the most recent studies point to the importance of the slope as a strong control for long term evolution (Ciarletta et al., 2019; Deng and Wu, 2020; Ribó et al., 2020).

The conceptual behaviour model for barrier shorefaces as explained by Cooper et al. (2018) describes three modes (keep-up, give-up and catch-up) of shoreface response to sea level rise (Figure 8). In this model, the rate of sea-level rise is a key determinant of shoreline behaviour but other internal factors (sediment supply, sediment volume and basement erodibility), also play a role. At mesoscale the geological inheritance dominates shoreface morphology and conditions the response to forcing through sea-level change and storm events. Knowledge of the contribution of shoreface dynamics to the nearshore stratigraphy, and in particular the processes that contribute to development of wave ravinement (erosion) surfaces (Zecchin et al., 2019), has important implications for determination of former sea levels from seismic stratigraphic records as shown by Plets et al. (2019). Shoreface deposits are frequently found in the geological record in preference to beach units. This shows their propensity for preservation by burial or overtopping. propensity for preservation by burial or overstepping) few studies utilizing such deposits to infer the morphodynamics of the shoreface over longer timescales. 


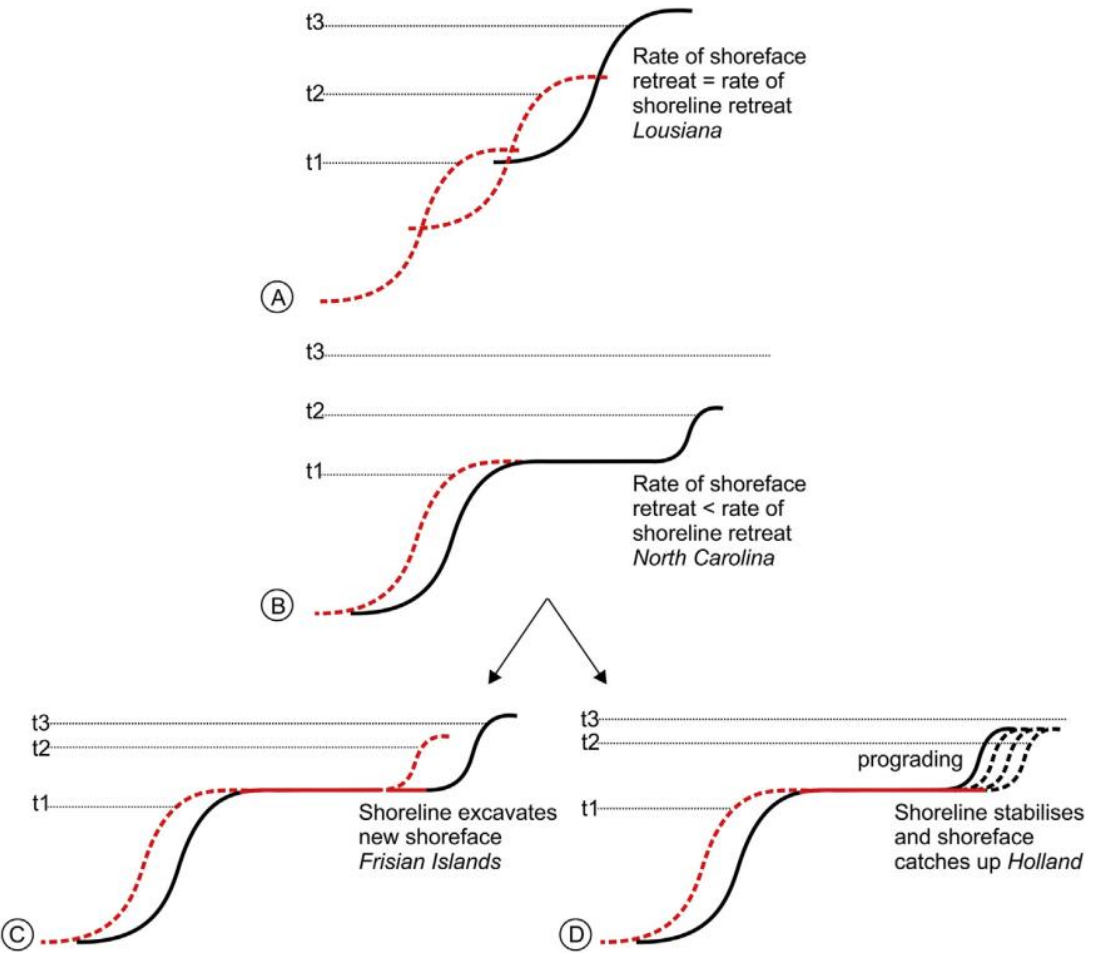

Figure 8. (colour) Diagram of barrier-shoreface retreat mode. A. Barrier and shoreface retreat at equal rates (keep-up). B. Shoreface retreat slower than barrier C\&D. Shoreface "catch-up" with t1 t2 t3 the successive stages of sea level rise. From Cooper et al. (2018)

\subsection{Shoreface-shoreline interactions}

During storm events sediment can be transported offshore to the lower shoreface (Niedoroda et al., 1984; Preston et al., 2018), and since it is then beyond the depth of closure, it is then considered lost to the coastal system. However, advances in the study of the role of the shoreface in the coastal system and sediment budget suggest that shoreface sediment (even beyond the depth of closure) might in fact play a key role in nearshore morphodynamics. Indeed, several studies (Billy et al., 2013; Brunel et al., 2014; Lazarus and Murray, 2011; Safak et al., 2017; Schupp et al., 2006; Thomas et al., 2011; Valvo et al., 2006) have linked shoreline shape and mesoscale variation patterns to adjacent shoreface setting.

Frihy et al. (1991) examined the link between shoreline evolution and nearshore bathymetric change in the Nile Delta, Egypt, and found no significant relationship between shoreline change and nearshore (i.e. shoreface) sediment texture, slope or depth. They did, however, attribute erosion and accretion 
patterns to movement of eroded sediment or sediment from offshore sources, suggesting that the shoreface might contribute to shoreline dynamics.

Wijnberg (2002), found no correlation between decadal coastal behaviour and sediment characteristics or offshore hydrodynamics on the Dutch coast but instead linked spatial changes in decadal behaviour to variation in shoreface morphology, especially the presence of "terrace like features" on the shoreface linking shoreface morphology and coastal behaviour. Similarly, Cooper et al. (2004) linked nearshore behaviour to sediment accumulation and associated bathymetric change on the shoreface.

Miselis and McNinch (2006), explored the relationship between shoreline variations and nearshore sediment volume in North Carolina, and established that the volume of sediment stored on the shoreface was correlated with decadal shorelines over decadal timescales. Sediment-poor shorefaces were associated with smaller shoreline change rates than sediment-rich shorefaces. shoreface in the coastal system, for example Goff et al. (2015) examined the impact of hurricane Sandy on the shoreface and found that "sand ridges and sorted bedforms appear to act as a regulator of storm-forced erosion of material beneath the modern sand layer" thereby limiting erosion of older sediment as a form of supply of modern sediment available for transport. Hapke et al. (2016), applied statistical analysis to correlate shoreline response of Fire Island with potential controls, especially storm processes and underlying shoreface geology. The correlation analysis suggested (p.52) that: "[long term shoreline] patterns result from an unresolved combination of, or feedback between, storm processes and framework geology (bathymetric variability and sediment availability)". area and evidence of onshore-directed sediment transport across the shoreface (Hapke et al., 2010; Schwab et al., 2013, 2000). Those studies show that the shoreface acts as a source and/or a conduit

677 for onshore sediment flux and has a role in foreshore long-term ( $>10^{1}$ years) morphodynamics; there 
678 is an apparent link between the volume of shoreface sediment and foreshore behaviour. Safak et al.

679 (2017) subsequently used a three-dimensional, hydrodynamic-based model to examine the effects of shoreface connected sand ridges on shoreline variability at Fire Island. Their results show that hydrodynamic processes and sediment flux are controlled by the effects of offshore geologic framework and that cross-shore flows between the shelf and the coast (i.e. flow on the shoreface) influence coastal evolution and shoreline variability at decadal time scales. alignment' between shoreline erosional hotspots and shore-oblique bar and associated outcrops. A subsequent study of the same area by Schupp et al. (2006), correlated areas of high shoreline variability with shore-oblique bar and gravel outcrops but with a spatial offset. These observations reinforce the idea that the shoreface morphology (which seems to reflect sediment volume and geological control) constrains or influences foreshore dynamics in some way. Similarly in South Carolina, Denny et al. (2013) linked stable shorelines to adjacent sediment-poor, erosion-resistant shorefaces, whereas the more variable portions of the shoreline occur around portions of the coast rich in sediment and with large sand bodies. Another study (Oakley et al., 2019) on a North-American shoreface (Rhode Island, US) did not find the shoreface sediment volume to be a good predictor of mesoscale shoreline variation, but hypothesize that the alongshore variations in shoreline variation patterns relates to the antecedent morphology of the shoreface and its heterogeneous nature. Shoreface sand bodies have been shown to exert a strong influence on foreshore change. Sand banks have been shown to decay onshore and provide sediment from the shoreface to the beach-dune system (Aagaard et al., 2004; Anthony, 2013; Anthony et al., 2006; Héquette and Aernouts, 2010; Héquette et al., 2013; Thomas et al., 2011; Verwaest et al., 2020). The opposite phenomenon (offshore bar breakdown followed by transport of sediment from the beach to the lower shoreface) has been documented by Aagaard (2011) on the Danish North Sea coast. 
On a longer time scale ( $>10^{3}$ years), Kinsela et al. (2016) showed through modelling of south-eastern

Australian beaches, that the shoreface contributed around $80 \%$ of the sand involved in the growth of Holocene strand plains. They suggest that similar processes might still contribute to contemporary shoreline stability. In the same region, Cowell et al. (2001) found that 'the annual net supply residual (of offshore sand) is cumulative and would grow to exceed the beach-cut/fill volume after only several decades', supporting the idea that the shoreface can be an important source of foreshore sand in the longer term.

\section{Discussion}

\subsection{Shoreface definition and morphodynamics}

The shoreface is a transition zone between surfzone/beachface and the shelf within which wave shoaling and sediment transport take place. In the face of multiple and conflicting definitions and terminology in the literature, the definition of the shoreface requires standardization. We propose that its landward limit be the outer edge of the surf zone (or the outermost bar) during fairweather/modal conditions, and where this is absent, the seaward edge of the swash zone (or the beach step). This can be justified on the marked difference in nature of wave-driven morphodynamics, pre- and post-breaking. The surf zone is dominated by wave breaking, (and associated processes such as reformation and secondary wave motions or rip currents etc.) (Dally, 2005) and is therefore morphodynamically distinct from the shoreface, not a part of it (Figure 9). Although energetic conditions may periodically extend the surf zone seaward, the most persistent process in the upper shoreface is wave shoaling. 


\section{Zonation of the Shoreface}

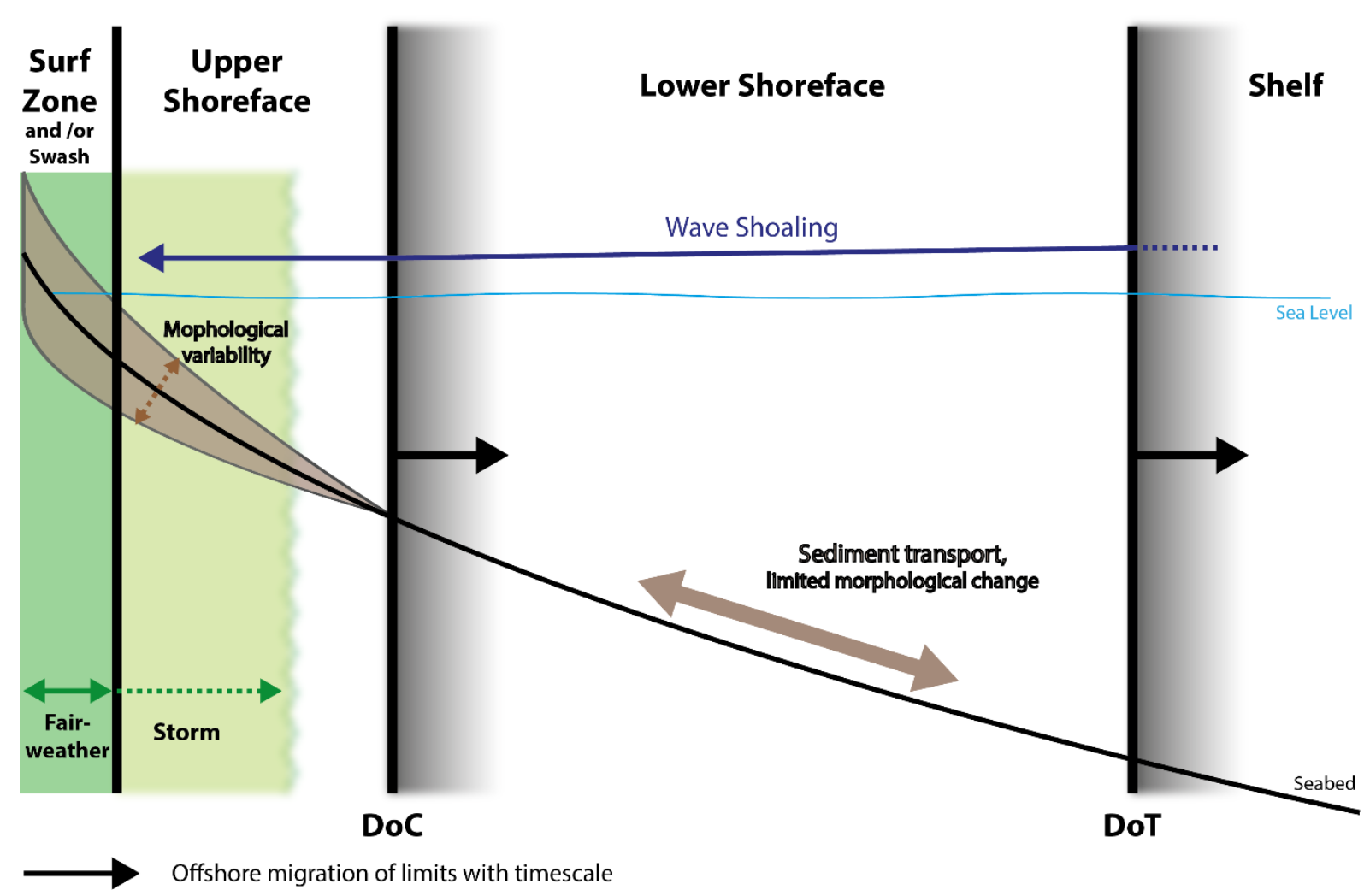

Figure 9: Definition of the shoreface, showing upper and lower shoreface limits. The surf zone is represented in dark green, with light green areas in the upper shoreface representing episodic expansion of the surf zone during energetic events. Brown arrows depict bidirectional movement of sediment in the shoreface and resulting morphological variability.

The shoreface is made up of two morphodynamically distinct units, namely the upper and lower shoreface. They are divided by the DoC and the outer limit of the lower shoreface is the threshold at which waves start to significantly impact the bottom at the mesoscale. We propose to use the Valiente et al. (2019) depth of transport (DoT) as a calculable boundary for the outer limit of the shoreface at the mesoscale. Upper and lower shorefaces each exhibit distinctive morphodynamics (Table 1). The shoreface role in adjacent nearshore (surfzone and swash zone) dynamics is manifest in (a) attenuating waves as they move onshore and (b) as both a sediment source and sink at variable (largely event-driven) timescales.

Upper and Lower shorefaces can be differentiated by their dynamics which play out at different spatiotemporal scales. Whilst the upper shoreface is active on a short (seasonal) temporal and small spatial scale $\left(<10^{0}\right.$ to $10^{1}$ years and around $\left.10^{0} \mathrm{~km}\right)$, the lower shoreface is active over larger scales $\left(10^{1}\right.$ to $10^{2}$ 
years and over $10^{1} \mathrm{Km}$ ). Because of its mesoscale behaviour, the lower shoreface has often been considered inert and non-influential in terms of coastal dynamics (Hoekstra et al., 1999). The upper shoreface is dominated by wave shoaling and periodic seaward excursions of the surfzone. This is responsible for the morphological variability that occurs on the upper shoreface at seasonal to decadal timescales. The lower shoreface is dominated by oscillatory wave motions that transport sediment but which create morphological change only at long timescales ( $>10^{1}$ years).

All shoreface morphodynamic limits exhibit spatio-temporal variability as they can be influenced by water level variations (tides, surges etc.), and variation in storminess with an offshore displacement of the previously cited limits during energetic events, for example. This highlights the interconnectivity between the shoreface zones and adjacent environments. Linkages and overlaps exist between the different zones, particularly at their boundaries. At the junctions between the zones sediment exchanges occur as the boundaries shift. For example, Aagaard (2014) quantified the supply from the lower to the upper shoreface and found it to be coherent with bar migration and aeolian accretion rates. Future targeted research might be able to provide quantifiable limits for the shoreface boundaries based on ratios of morphological change, for example, but thus far, this is not feasible because of the paucity of observations.

\subsection{Sediment supply and shoreface morphology}




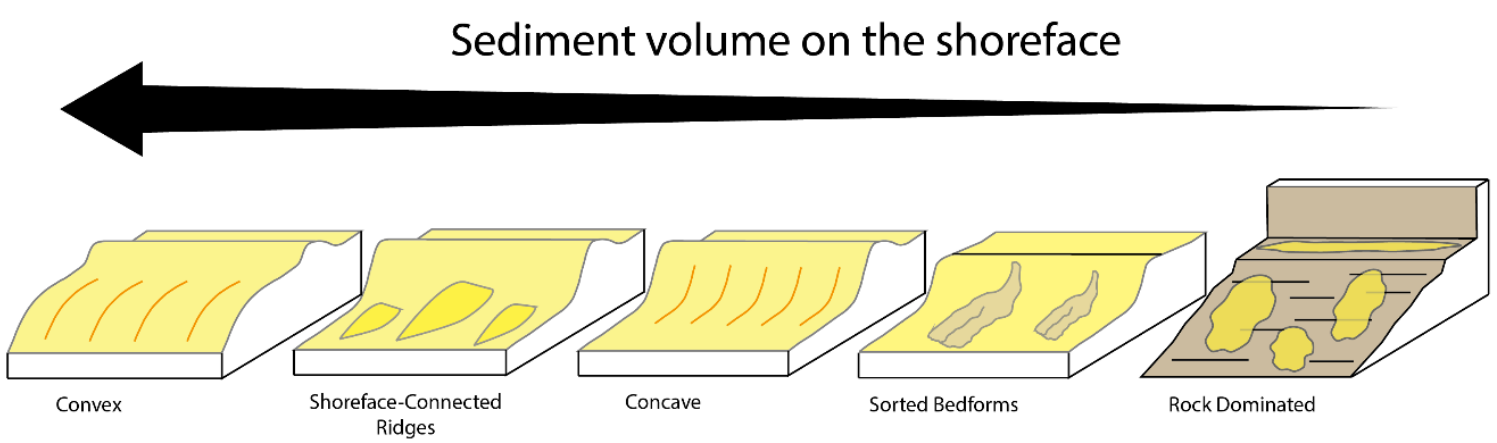

Figure 10: Shoreface morphological classification as a function of sediment supply. Typical morphologies associated with, (increasing) sediment volume on the shoreface from a sediment starved erosive (far right) shoreface to a prograding shoreface (far left) with intermediate morphologies indicating the augmentation of available shoreface sediment.

The literature shows that a wide variety of shoreface morphologies exist in nature (Athanasiou et al., 2019; Kinsela et al., 2020). It is unlikely these variations are linked solely to variations in wave conditions. One of the major factors controlling this variability in morphology seems to be sediment supply (or availability) and more specifically, the sedimentary bedforms associated with sedimentpoor and sediment-rich shorefaces. Bedforms are an indicator of the presence (or deficit) of sediment on the shoreface. Offshore of Fire Island (Locker et al., 2017; Schwab et al., 2017) increasing sediment abundance is reflected in the successive development of sorted bedforms and SCRs. Banks, ridges and similar features are indicators of sediment-rich areas while sorted bedforms are more typical of sediment-depleted areas. For example, some shoreface attached sand ridges have been determined to originate from relict tidal deltas (McBride and Moslow, 1991) supporting the hypothesis that these features originate in sediment-rich areas.

We propose a tentative classification of shoreface morphologies based on increasing sediment abundance (Figure 10). Shorefaces that lack sediment are likely to be much more erosional. With the addition of a limited amount of sediment, sorted bedforms develop with underlying lag deposits exposed between sandy areas of positive relief. Increased sediment supply can then lead to development of SCRs either from relict sediment sources (e.g. submerged ebb deltas) or 
contemporary inputs. Evidence of the link is present in the longshore variation in shoreface morphology offshore of Fire Island, for example where onshore sediment abundance and accretion is mirrored by offshore SCRs at the downdrift limit of the barrier. We surmise that increased sediment abundance ultimately creates convex shoreface morphologies. At longer timescales ( $>10^{1}$ to $10^{1}$ years) shorefaces might evolve along this spectrum according to whether sediment supply is abundant or absent_(Deaton et al., 2017; Raff et al., 2018; Shawler et al., 2019). The equilibrium shoreface profile in this conceptual scheme is one of a spectrum of possible morphologies.

The influence of shoreface morphology on the overall mesoscale coastal morphodynamics, however, is still unclear, especially in terms of its contribution to the overall sediment budget. While in some locations the shoreface acts as a net sediment source (Denny et al., 2013; Ruggiero et al., 2016; Verwaest et al., 2020), for other regions it seems to be a sink (Aagaard, 2011; Finkl, 2004). It is clear, however, that sediment exchanges within and between the shoreface and adjacent environments is strongly episodic and likely strongly influenced by geological setting (sediment supply and antecedent topography). In addition to the implicit geological control on such exchanges, these sediment transfers are likely to be spatially and temporally variable. Whilst the impact of the variable shoreface morphologies on the foreshore is still not fully understood, several studies have established links to observed behavioural shoreline patterns, demonstrating the potential importance of shoreface morphology to the overall coastal dynamics (Latapy et al., 2020; Verwaest et al., 2020; Wijnberg, 2002). Unfortunately, the paucity of datasets of shoreface morphology, preclude detailed insights into the mesoscale dynamics of these shoreface morphologies and the adjacent coasts.

The evidence shows that the shoreface is morphodynamically distinct but it does play an important role in nearshore sediment exchanges and is an important conditioner of processes in the surfzone and landward. 
The field of coastal geoscience has developed around the principle of equilibrium, with the first mention of equilibrium profile dating as far back as the early $19^{\text {th }}$ century (Fenneman, 1902). Since then, research on coastal morphology and processes has mostly been focused on the beach and surf zone through which the dynamic principles that control beach and surf zone morphology have been developed. The Wright and Short (1984) model, which classifies beach state on a spectrum ranging from reflective to dissipative according to their morphology, was subsequently refined and adapted to account for further driving factors such as tides (Jackson et al., 2005; Loureiro et al., 2013; Masselink and Short, 1993; Short and Jackson, 2013)

Whereas the drivers of beach morphology have been well-constrained, the same is not true of the shoreface, possibly because of the gap in both spatial and temporal data that once existed. Spatial data availability is now being considerably enhanced by technical advances in data acquisition but the spatiotemporal scale at which shoreface dynamics operate still poses problems for empirical studies.

Much in the same way as for beaches and surf zones the shoreface can assume a spectrum of forms (Kinsela et al., 2020) that do not result from just grain size and wave climate forcing but rather a multiplicity of factors. Such a conceptual model would help create a much more realistic representation of existing shoreface morphologies worldwide.

Our proposed shoreface classification based on sediment supply provides one model that may prove to be universally applicable and could serve to coordinate studies focusing on very different spatiotemporal scales. Future approaches to understanding shoreface dynamics should consider this and the diverse factors that ultimately influence them at meso- and geological scales. This will improve scientific, engineering and management understanding of shoreface dynamics per se as well as add important new insights into their association with beach and shoreline behaviour.

\section{Acknowledgements}


822 This work was supported through funding from a DfE International research Award to Klervi Hamon-

823 Kerivel. This work was also supported by ISblue project, Interdisciplinary graduate school for the blue 824 planet (ANR-17-EURE-0015) and co-funded by a grant from the French government under the program 825 "Investissements d'Avenir". It is a contribution to NERC project NE/H024301/1 "Late Glacial sea level 826 minima".

827

828 Declarations of interest: none

829 


\begin{tabular}{|c|c|c|c|c|}
\hline & \multicolumn{2}{|l|}{ Upper Shoreface } & \multicolumn{2}{|c|}{ Lower Shoreface } \\
\hline Limits & $\begin{array}{l}\text { Fairweather } \\
\text { Surf/Swash zone }\end{array}$ & \multicolumn{2}{|c|}{$\begin{array}{l}\text { Morphologically active } \\
\text { zone }\end{array}$} & $\begin{array}{l}\text { Long-term limit of } \\
\text { intense } \\
\text { transport }\end{array}$ \\
\hline Calculation & & \multicolumn{2}{|c|}{ Hallermeier's DoC } & Valiente's DoT \\
\hline $\begin{array}{l}\text { Characteristic time scale of } \\
\text { morphodynamics }\end{array}$ & \multicolumn{2}{|c|}{ Seasonal to annual $<10^{\circ}$ years } & \multicolumn{2}{|c|}{ Mesoscale $>10^{1}$ years } \\
\hline Main drivers of morphology & \multicolumn{2}{|c|}{ Hydrodynamics (wave, wind, tide...) } & \multicolumn{2}{|c|}{$\begin{array}{l}\text { Sediment supply/availability/size } \\
\text { Geological framework \& morphology }\end{array}$} \\
\hline Hydrodynamics & $\begin{array}{l}\text { Wave shoaling, a } \\
\text { during storm conc }\end{array}$ & e breaking & Wave sho & ing \\
\hline \multirow{2}{*}{$\begin{array}{l}\text { Other drivers of the } \\
\text { morphology }\end{array}$} & \multicolumn{2}{|c|}{ Geology \& sediments } & \multicolumn{2}{|c|}{ Hydrodynamics } \\
\hline & \multicolumn{4}{|c|}{$\begin{array}{l}\text { Antecedent morphology, slope } \\
\text { Storm grouping, ocean patterns } \\
\text { Biological processes }\end{array}$} \\
\hline
\end{tabular}


Aagaard, T., 2011. Sediment transfer from beach to shoreface: The sediment budget of an accreting beach on the Danish North Sea Coast. Geomorphology 135, 143-157.

Aagaard, T., 2014. Sediment supply to beaches: cross-shore sand transport on the lower shoreface. Journal of Geophysical Research: Earth Surface 119, 913-926.

Aagaard, T., Davidson-Arnott, R., Greenwood, B., Nielsen, J., 2004. Sediment supply from shoreface to dunes: linking sediment transport measurements and long-term morphological evolution. Geomorphology 60, 205-224.

Aagaard, T., Greenwood, B., Hughes, M., 2013. Sediment transport on dissipative, intermediate and reflective beaches. Earth-science reviews 124, 32-50.

Aagaard, T., Kroon, A., 2019. Decadal behaviour of a washover fan, Skallingen Denmark. Earth Surface Processes and Landforms 44, 1755-1768.

Aagaard, T., Kroon, A., Greenwood, B., Hughes, M.G., 2010. Observations of offshore bar decay: Sediment budgets and the role of lower shoreface processes. Continental Shelf Research 30, 1497-1510.

Aleman, N., Robin, N., Certain, R., Anthony, E., Barusseau, J.-P., 2015. Longshore variability of beach states and bar types in a microtidal, storm-influenced, low-energy environment. Geomorphology 241, 175-191.

Anthony, E.J., 2008. A Medium-Term (Meso-scale) Approach to Beach and Barrier Processes, in: Shore Processes and Their Palaeoenvironmental Applications. Elsevier, pp. 241-261.

Anthony, E.J., 2013. Storms, shoreface morphodynamics, sand supply, and the accretion and erosion of coastal dune barriers in the southern North Sea. Geomorphology 199, 8-21.

Anthony, E.J., Vanhee, S., Ruz, M.-H., 2006. Short-term beach-dune sand budgets on the north sea coast of France: Sand supply from shoreface to dunes, and the role of wind and fetch. Geomorphology 81, 316-329.

Aragonés, L., Pagán, J., López, I., Navarro-González, F., Villacampa, Y., 2019. Galerkin’s formulation of the finite elements method to obtain the depth of closure. Science of The Total Environment 660, 1256-1263.

Aragonés, L., Pagán, J.I., López, I., Serra, J.C., 2018. Depth of closure: New calculation method based on sediment data. International Journal of Sediment Research 33, 198-207.

Athanasiou, P., Van Dongeren, A., Giardino, A., Vousdoukas, M., Gaytan-Aguilar, S., Ranasinghe, R., 2019. Global distribution of nearshore slopes with implications for coastal retreat. Earth system science data 11, 1515-1529.

Aubrey, D.G., 1979. Seasonal patterns of onshore/offshore sediment movement. Journal of Geophysical Research: Oceans 84, 6347-6354. 
Austin, M., Masselink, G., O’Hare, T., Russell, P., 2009. Onshore sediment transport on a sandy beach under varied wave conditions: Flow velocity skewness, wave asymmetry or bed ventilation? Marine Geology 259, 86-101.

Backstrom, J., Jackson, D., Cooper, A., Loureiro, C., 2015. Contrasting geomorphological storm response from two adjacent shorefaces. Earth Surface Processes and Landforms 40, 2112-2120.

Backstrom, J., Jackson, D., Cooper, J., 2007. Shoreface dynamics of two high-energy beaches in Northern Ireland. Journal of Coastal Research 50, 594-8.

Bakker, A., Brinkkemper, J., Steen, F., Tissier, M., Ruessink, B., 2016. Cross-shore sand transport by infragravity waves as a function of beach steepness. Journal of Geophysical Research: Earth Surface 121, 1786-1799.

Barnard, P., Erikson, L.H., Hansen, J., 2009. Monitoring and modeling shoreline response due to shoreface nourishment on a high-energy coast. Journal of Coastal Research 29-33.

Bertin, X., de Bakker, A., Van Dongeren, A., Coco, G., Andre, G., Ardhuin, F., Bonneton, P., Bouchette, F., Castelle, B., Crawford, W.C., others, 2018. Infragravity waves: From driving mechanisms to impacts. Earth-Science Reviews 177, 774-799.

Billy, J., Robin, N., Certain, R., Hein, C., Berné, S., 2013. Barrier shoreline evolution constrained by shoreface sediment reservoir and substrate control: The Miquelon-Langlade Barrier, NW Atlantic. Journal of Coastal Research 65, 2089-2094.

Bird, E., 1985. Coastline Changes: a Global Review. Wiley.

Birkemeier, W.A., 1985. Field data on seaward limit of profile change. Journal of Waterway, Port, Coastal, and Ocean Engineering 111, 598-602.

Boon, J.D., Green, M.O., 1988. Caribbean beach-face slopes and beach equilibrium profiles. Coastal Engineering Proceedings 1, 1618-1630.

Bowen, A., 1980. Simple models of nearshore sedimentation: Beach profiles and longshore bars, in: S.B. McCann (Ed.), The Coastline of Canada. Geological Survey of Canada, pp. $1-11$.

Browder, A.G., McNinch, J.E., 2006. Linking framework geology and nearshore morphology: correlation of paleo-channels with shore-oblique sandbars and gravel outcrops. Marine Geology 231, 141-162.

Brunel, C., Certain, R., Sabatier, F., Robin, N., Barusseau, J., Aleman, N., Raynal, O., 2014. 20th century sediment budget trends on the Western Gulf of Lions shoreface (France): An application of an integrated method for the study of sediment coastal reservoirs. Geomorphology 204, 625-637.

Calvete, D., Falqués, A., De Swart, H., Walgreen, M., 2001a. Modelling the formation of shoreface-connected sand ridges on storm-dominated inner shelves. Journal of Fluid 
Mechanics 441, 169-193.

Calvete, D., Walgreen, M., Swart, H. de, Falqués, A., 2001b. A model for sand ridges on the shelf: Effect of tidal and steady currents. Journal of Geophysical Research: Oceans 106, 9311-9325.

Castelle, B., Scott, T., Brander, R., McCarroll, R., 2016. Rip current types, circulation and hazard. Earth-Science Reviews 163, 1-21.

Ciarletta, D.J., Lorenzo-Trueba, J., Ashton, A., 2019. Mechanism for retreating barriers to autogenically form periodic deposits on continental shelves. Geology 47, 239-242.

Clifton, H.E., 2005. Shoreface, in: Encyclopedia of Coastal Science. Springer, pp. 877-881.

Cooper, J., Jackson, D., Navas, F., McKenna, J., Malvarez, G., 2004. Identifying storm impacts on an embayed, high-energy coastline: examples from western Ireland. Marine Geology 210, 261-280.

Cooper, J., Navas, F., 2004. Natural bathymetric change as a control on century-scale shoreline behavior. Geology 32, 513-516.

Cooper, J.A.G., Green, A.N., Loureiro, C., 2018. Geological constraints on mesoscale coastal barrier behaviour. Global and Planetary Change 168, 15-34.

Cooper, J.A.G., Pilkey, O.H., 2004. Sea-level rise and shoreline retreat: time to abandon the Bruun Rule. Global and Planetary change 43, 157-171.

Cowell, P., Hanslow, D., Meleo, J., 1999. The shoreface. Handbook of beach and shoreface morphodynamics 3, 39-71.

Cowell, P., Roy, P., Jones, R., 1995. Simulation of large-scale coastal change using a morphological behaviour model. Marine Geology 126, 45-61.

Cowell, P.J., Kinsela, M.A., 2018. Shoreface controls on barrier evolution and shoreline change, in: Barrier Dynamics and Response to Changing Climate. Springer, pp. 243-275.

Cowell, P.J., Stive, M.J., Roy, P.S., Kaminsky, G.M., Buijsman, M.C., Thom, B.G., Wright, L.D., 2001. Shoreface sand supply to beaches, in: Coastal Engineering 2000. pp. 24952508 .

Dally, W., 2005. Surf zone processes. Encyclopedia of coastal science 18, 929-935.

Dashtgard, S.E., Gingras, M.K., MacEachern, J.A., 2009. Tidally modulated shorefaces. Journal of Sedimentary Research 79, 793-807.

Dashtgard, S.E., MacEachern, J.A., Frey, S.E., Gingras, M.K., 2012. Tidal effects on the shoreface: towards a conceptual framework. Sedimentary Geology 279, 42-61. 
Dean, R., 1977. Equilibrium beach profiles: US Atlantic and Gulf coasts. Newark, University of Delaware. Ocean Engineering Report No 12, 151-165.

Dean, R.G., 1991. Equilibrium beach profiles: characteristics and applications. Journal of Coastal Research 7, 53-84.

Deaton, C.D., Hein, C.J., Kirwan, M.L., 2017. Barrier island migration dominates ecogeomorphic feedbacks and drives salt marsh loss along the Virginia Atlantic Coast, USA. Geology 45, 123-126.

Deng, J., Wu, J., 2020. Assessing the effects of shoreface profile concavity on long-term shoreline changes: an exploratory study Geo-Marine Letters.

Denny, J.F., Schwab, W.C., Baldwin, W.E., Barnhardt, W.A., Gayes, P.T., Morton, R.A., Warner, J.C., Driscoll, N.W., Voulgaris, G., 2013. Holocene sediment distribution on the inner continental shelf of northeastern South Carolina: implications for the regional sediment budget and long-term shoreline response. Continental Shelf Research 56, 56-70.

Durán, R., Guillén, J., Rivera, J., Lobo, F., Muñoz, A., Fernández-Salas, L., Acosta, J., 2018. Formation, evolution and present-day activity of offshore sand ridges on a narrow, tideless continental shelf with limited sediment supply. Marine Geology 397, 93-107.

Falques, A., Calvete, D., De Swart, H., Dodd, N., 1999. Morphodynamics of shorefaceconnected ridges, in: Coastal Engineering 1998. pp. 2851-2864.

Fenneman, N.M., 1902. Development of the profile of equilibrium of the subaqueous shore terrace. The Journal of Geology 10, 1-32.

Finkl, C.W., 2004. Leaky valves in littoral sediment budgets: loss of nearshore sand to deep offshore zones via chutes in barrier reef systems, southeast coast of Florida, USA. Journal of Coastal Research 20, 605-611.

Frihy, O., Nasr, S., Ahmed, M., El Raey, M., 1991. Temporal shoreline and bottom changes of the inner continental shelf off the Nile Delta, Egypt. Journal of Coastal Research 7, $465-475$.

Frihy, O.E., Hassan, M.S., Deabes, E.A., Abd El Moniem, A.B., 2008. Seasonal wave changes and the morphodynamic response of the beach-inner shelf of Abu Qir Bay, Mediterranean coast, Egypt. Marine Geology 247, 145-158.

Fruergaard, M., Andersen, T.J., Johannessen, P.N., Nielsen, L.H., Pejrup, M., 2013. Major coastal impact induced by a 1000-year storm event. Scientific reports 3, 1-7.

Gallop, S.L., Kennedy, D.M., Loureiro, C., Naylor, L.A., Muñoz-Pérez, J.J., Jackson, D.W., Fellowes, T.E., 2020. Geologically controlled sandy beaches: Their geomorphology, morphodynamics and classification. Science of the Total Environment 139123.

George, D.A., Hill, P.S., 2008. Wave climate, sediment supply and the depth of the sand-mud transition: a global survey. Marine Geology 254, 121-128. 
Goff, J.A., Flood, R.D., Austin Jr, J.A., Schwab, W.C., Christensen, B., Browne, C.M., Denny, J.F., Baldwin, W.E., 2015. The impact of Hurricane Sandy on the shoreface and inner shelf of Fire Island, New York: Large bedform migration but limited erosion. Continental Shelf Research 98, 13-25.

Goff, J.A., Mayer, L.A., Traykovski, P., Buynevich, I., Wilkens, R., Raymond, R., Glang, G., Evans, R.L., Olson, H., Jenkins, C., 2005. Detailed investigation of sorted bedforms, or "rippled scour depressions," within the Martha's Vineyard Coastal Observatory, Massachusetts. Continental Shelf Research 25, 461-484.

Goodwin, I.D., Freeman, R., Blackmore, K., 2013. An insight into headland sand bypassing and wave climate variability from shoreface bathymetric change at Byron Bay, New South Wales, Australia. Marine Geology 341, 29-45.

Green, M.O., Vincent, C.E., Trembanis, A.C., 2004. Suspension of coarse and fine sand on a wave-dominated shoreface, with implications for the development of rippled scour depressions. Continental Shelf Research 24, 317-335.

Grunnet, N.M., Ruessink, B., 2005. Morphodynamic response of nearshore bars to a shoreface nourishment. Coastal Engineering 52, 119-137.

Guerrero, Q., Guillén, J., Durán, R., Urgeles, R., 2018. Contemporary genesis of sand ridges in a tideless erosional shoreface. Marine Geology 395, 219-233.

Guisado-Pintado, E., Jackson, D.W., 2018. Multi-scale variability of storm Ophelia 2017: The importance of synchronised environmental variables in coastal impact. Science of The Total Environment 630, 287-301.

Guisado-Pintado, E., Jackson, D.W., 2019. Coastal impact from high-energy events and the importance of concurrent forcing parameters: the cases of Storm Ophelia (2017) and Storm Hector (2018) in NW Ireland. Frontiers in Earth Science 7, 190.

Gutierrez, B.T., Voulgaris, G., Thieler, E.R., 2005. Exploring the persistence of sorted bedforms on the inner-shelf of Wrightsville Beach, North Carolina. Continental Shelf Research 25, 65-90.

Hallermeier, R.J., 1978. Uses for a calculated limit depth to beach erosion, in: Coastal Engineering 1978. pp. 1493-1512.

Hallermeier, R.J., 1981. A profile zonation for seasonal sand beaches from wave climate. Coastal engineering 4, 253-277.

Hampson, G.J., Storms, J.E., 2003. Geomorphological and sequence stratigraphic variability in wave-dominated, shoreface-shelf parasequences. Sedimentology 50, 667-701.

Hanna, J.E., Cooper, J., 2002. Mesoscale morphological changes on linear, nearshore sandbanks, Co. Wexford, SE Ireland. Journal of Coastal Research SI 36, 356-364.

Hapke, C.J., Lentz, E.E., Gayes, P.T., McCoy, C.A., Hehre, R., Schwab, W.C., Williams, S.J., 2010. A review of sediment budget imbalances along Fire Island, New York: can 
nearshore geologic framework and patterns of shoreline change explain the deficit? Journal of Coastal Research 26, 510-522.

Hapke, C.J., Plant, N.G., Henderson, R.E., Schwab, W.C., Nelson, T.R., 2016. Decoupling processes and scales of shoreline morphodynamics. Marine Geology 381, 42-53.

Héquette, A., Aernouts, D., 2010. The influence of nearshore sand bank dynamics on shoreline evolution in a macrotidal coastal environment, Calais, Northern France. Continental Shelf Research 30, 1349-1361.

Héquette, A., Anthony, E.J., Ruz, M.-H., Maspataud, A., Aernouts, D., Hemdane, Y., 2013. The influence of nearshore sand banks on coastal hydrodynamics and sediment transport, northern coast of France, in: Proceedings Coastal Dynamics. pp. 801-810.

Héquette, A., Desrosiers, M., Hill, P.R., Forbes, D.L., 2001. The influence of coastal morphology on shoreface sediment transport under storm-combined flows, Canadian Beaufort Sea. Journal of Coastal Research 17, 507-516.

Héquette, A., Hemdane, Y., Anthony, E.J., 2008a. Sediment transport under wave and current combined flows on a tide-dominated shoreface, northern coast of France. Marine geology $249,226-242$.

Héquette, A., Hemdane, Y., Anthony, E.J., 2008b. Determination of sediment transport paths in macrotidal shoreface environments: a comparison of grain-size trend analysis with nearbed current measurements. Journal of Coastal Research 24, 695-707.

Héquette, A., Hill, P.R., 1993. Storm-generated currents and offshore sediment transport on a sandy shoreface, Tibjak Beach, Canadian Beaufort Sea. Marine geology 113, 283-304.

Hinton, C., Nicholls, R.J., 1999. Spatial and temporal behaviour of depth of closure along the Holland coast, in: Coastal Engineering 1998. pp. 2913-2925.

Hoekstra, P., Houwman, K., Ruessink, G., 1999. The role and time scale of cross-shore sediment exchange for a barrier island shoreface, in: Coastal Sediments. pp. 519-534.

Howell, J.A., Skorstad, A., MacDonald, A., Fordham, A., Flint, S., Fjellvoll, B., Manzocchi, T., 2008. Sedimentological parameterization of shallow-marine reservoirs. Petroleum Geoscience 14, 17-34.

Huisman, B., Walstra, D.-J., Radermacher, M., De Schipper, M., Ruessink, G., 2019. Observations and modelling of shoreface nourishment behaviour. Journal of Marine Science and Engineering 7, 59.

Inman, D.L., Adams, P.N., 2005. Bedforms and closure depth on equilibrium beaches. Scripps Institution of Oceanography, Technical Report.

Jackson, D., Cooper, J., Del Rio, L., 2005. Geological control of beach morphodynamic state. Marine Geology 216, 297-314. 
King, E., Conley, D., Masselink, G., Leonardi, N., McCarroll, R., Scott, T., 2019. The impact of waves and tides on residual sand transport on a sediment-poor, energetic, and macrotidal continental shelf. Journal of Geophysical Research: Oceans 124, 4974-5002.

Kinsela, M.A., Daley, M.J., Cowell, P.J., 2016. Origins of Holocene coastal strandplains in Southeast Australia: Shoreface sand supply driven by disequilibrium morphology. Marine Geology 374, 14-30.

Kinsela, M.A., Hanslow, D.J., Carvalho, R.C., Linklater, M., Ingleton, T.C., Morris, B.D., Allen, K.M., Sutherland, M.D., Woodroffe, C.D., 2020. Mapping the Shoreface of Coastal Sediment Compartments to Improve Shoreline Change Forecasts in New South Wales, Australia. Estuaries and coasts 1-27.

Kraus, N.C., Harikai, S., 1983. Numerical model of the shoreline change at Oarai Beach. Coastal Engineering 7, 1-28.

Larson, M., Kraus, N.C., Wise, R.A., 1999. Equilibrium beach profiles under breaking and non-breaking waves. Coastal Engineering 36, 59-85.

Latapy, A., Héquette, A., Nicolle, A., Pouvreau, N., 2020. Influence of shoreface morphological changes since the 19th century on nearshore hydrodynamics and shoreline evolution in Wissant Bay (northern France). Marine Geology 422, 106095.

Lazarus, E.D., Murray, A.B., 2011. An integrated hypothesis for regional patterns of shoreline change along the Northern North Carolina Outer Banks, USA. Marine Geology 281, 85-90.

Lee, G., Nicholls, R.J., Birkemeier, W.A., 1998. Storm-driven variability of the beachnearshore profile at Duck, North Carolina, USA, 1981-1991. Marine geology 148, 163 177.

Li, Y., Lark, M., Reeve, D., 2005. Multi-scale variability of beach profiles at Duck: a wavelet analysis. Coastal Engineering 52, 1133-1153.

Liu, S., Goff, J.A., 2018. Lower shoreface seismic stratigraphy and morphology off Fire Island, New York: Evidence for lobate progradation and linear erosion. Continental Shelf Research 163, 23-34.

Liu, S., Goff, J.A., Flood, R.D., Christensen, B., Austin Jr, J.A., 2018. Sorted bedforms off Western Long Island, New York, USA: Asymmetrical morphology and twelve-year migration record. Sedimentology 65, 2202-2222.

Locker, S.D., Miselis, J.L., Buster, N.A., Hapke, C.J., Wadman, H.M., McNinch, J.E., Forde, A.S., Stalk, C.A., 2017. Nearshore sediment thickness, Fire Island, New York. US Geological Survey Open-File Report 1024, 21.

Loureiro, C., Ferreira, Ó., Cooper, J.A.G., 2012a. Extreme erosion on high-energy embayed beaches: influence of megarips and storm grouping. Geomorphology 139, 155-171. 
Loureiro, C., Ferreira, Ó., Cooper, J.A.G., 2012b. Geologically constrained morphological variability and boundary effects on embayed beaches. Marine Geology 329, 1-15.

Loureiro, C., Ferreira, Ó., Cooper, J.A.G., 2013. Applicability of parametric beach morphodynamic state classification on embayed beaches. Marine Geology 346, 153-164.

Madricardo, F., Rizzetto, F., 2018. Shallow coastal landforms, in: Submarine Geomorphology. Springer, pp. 161-183.

Masselink, G., Short, A.D., 1993. The effect of tide range on beach morphodynamics and morphology: a conceptual beach model. Journal of Coastal Research 785-800.

McBride, R.A., Moslow, T.F., 1991. Origin, evolution, and distribution of shoreface sand ridges, Atlantic inner shelf, USA. Marine Geology 97, 57-85.

McNinch, J.E., 2004. Geologic control in the nearshore: shore-oblique sandbars and shoreline erosional hotspots, Mid-Atlantic Bight, USA. Marine Geology 211, 121-141.

Menier, D., Estournès, G., Mathew, M.J., Ramkumar, M., Briend, C., Siddiqui, N., Traini, C., Pian, S., Labeyrie, L., 2016. Relict geomorphological and structural control on the coastal sediment partitioning, North of Bay of Biscay. Zeitschrift für Geomorphologie 60, 67-74.

Menier, D., Mathew, M., Cherfils, J.-B., Ramkumar, M., Estournès, G., Koch, M., Guillocheau, F., Sedrati, M., Goubert, E., Gensac, E., others, 2019. Holocene sediment mobilization in the inner continental shelf of the Bay of Biscay: Implications for regional sediment budget offshore to onshore. Journal of Coastal Research 88, 110-121.

Mielck, F., Holler, P., Bürk, D., Hass, H., 2015. Interannual variability of sorted bedforms in the coastal German Bight (SE North Sea). Continental Shelf Research 111, 31-41.

Miselis, J.L., McNinch, J.E., 2006. Calculating shoreline erosion potential using nearshore stratigraphy and sediment volume: Outer Banks, North Carolina. Journal of Geophysical Research: Earth Surface 111.

Murray, A.B., Coco, G., Goldstein, E.B., 2014a. Cause and effect in geomorphic systems: Complex systems perspectives. Geomorphology 214, 1-9.

Murray, A.B., Goldstein, E.B., Coco, G., 2014b. The shape of patterns to come: from initial formation to long-term evolution. Earth Surface Processes and Landforms 39, 62-70.

Murray, A.B., Thieler, E.R., 2004. A new hypothesis and exploratory model for the formation of large-scale inner-shelf sediment sorting and "rippled scour depressions". Continental Shelf Research 24, 295-315.

Naffaa, M., Fanos, A., El Ganainy, A., 1995. Prediction of closure depth at the Nile delta coast. Alexandria Engineering Journal 34, 167-173.

Nicholls, R.J., Birkemeier, W.A., Hallermeier, R.J., 1997. Application of the depth of closure concept, in: Coastal Engineering 1996. pp. 3874-3887. 
Nicholls, R.J., Birkemeier, W.A., Lee, G., 1998. Evaluation of depth of closure using data from Duck, NC, USA. Marine Geology 148, 179-201.

Nicholls, R.J., Larson, M., Capobianco, M., Birkemeier, W.A., 1999. Depth of closure: improving understanding and prediction, in: Coastal Engineering 1998. pp. 2888-2901.

Niedoroda, A.W., Swift, D.J., 1981. Maintenance of the shoreface by wave orbital currents and mean flow: observations from the Long Island coast. Geophysical Research Letters 8, 337-340.

Niedoroda, A.W., Swift, D.J., Hopkins, T.S., Ma, C.-M., 1984. Shoreface morphodynamics on wave-dominated coasts. Marine Geology 60, 331-354.

Nnafie, A., de Swart, H., Calvete, D., Garnier, R., 2014. Effects of sea level rise on the formation and drowning of shoreface-connected sand ridges, a model study. Continental Shelf Research 80, 32-48.

Nnafie, A., de Swart, H.E., Calvete, D., Garnier, R., 2015. Dynamics of shoreface-connected and inactive sand ridges on a shelf, Part 2: The role of sea level rise and associated changes in shelf geometry. Continental Shelf Research 104, 63-75.

Oakley, B.A., Murphy, C., Varney, M., Hollis, R.J., 2019. Spatial Extent and Volume of the Shoreface Depositional Platform on the Upper Shoreface of the Glaciated Rhode Island South Shore. Estuaries and Coasts 1-20.

Ojeda, E., Ruessink, B., Guillen, J., 2008. Morphodynamic response of a two-barred beach to a shoreface nourishment. Coastal Engineering 55, 1185-1196.

Ortiz, A.C., Ashton, A.D., 2016. Exploring shoreface dynamics and a mechanistic explanation for a morphodynamic depth of closure. Journal of Geophysical Research: Earth Surface 121, 442-464.

Patterson, D., Nielsen, P., 2016. Depth, bed slope and wave climate dependence of long term average sand transport across the lower shoreface. Coastal Engineering 117, 113-125.

Pham, D.T., Gouramanis, C., Switzer, A.D., Rubin, C.M., Jones, B.G., Jankaew, K., Carr, P.F., 2017. Elemental and mineralogical analysis of marine and coastal sediments from Phra Thong Island, Thailand: Insights into the provenance of coastal hazard deposits. Marine Geology 385, 274-292.

Pilkey, O.H., Young, R.S., Riggs, S.R., Smith, A.S., Wu, H., Pilkey, W.D., 1993. The concept of shoreface profile of equilibrium: a critical review. Journal of Coastal Research 9, 255-278.

Plets, R.M., Callard, S.L., Cooper, J.A.G., Kelley, J.T., Belknap, D.F., Edwards, R.J., Long, A.J., Quinn, R.J., Jackson, D.W., 2019. Late Quaternary sea-level change and evolution of Belfast Lough, Northern Ireland: new offshore evidence and implications for sea-level reconstruction. Journal of Quaternary Science 34, 285-298. 
Preston, J., Hurst, M.D., Mudd, S.M., Goodwin, G.C., Newton, A.J., Dugmore, A.J., 2018. Sediment accumulation in embayments controlled by bathymetric slope and wave energy: Implications for beach formation and persistence. Earth Surface Processes and Landforms 43, 2421-2434.

Pretorius, L., Green, A.N., Cooper, J.A., 2018. Submerged beachrock preservation in the context of wave ravinement. Geo-Marine Letters 38, 19-32.

Raff, J.L., Shawler, J.L., Ciarletta, D.J., Hein, E.A., Lorenzo-Trueba, J., Hein, C.J., 2018. Insights into barrier-island stability derived from transgressive/regressive state changes of Parramore Island, Virginia. Marine Geology 403, 1-19.

Ribó, M., Goodwin, I.D., O’Brien, P., Mortlock, T., 2020. Shelf sand supply determined by glacial-age sea-level modes, submerged coastlines and wave climate. Scientific Reports $10,1-10$.

Richmond, B.M., Buckley, M., Etienne, S., Chagué-Goff, C., Clark, K., Goff, J., DomineyHowes, D., Strotz, L., 2011. Deposits, flow characteristics, and landscape change resulting from the September 2009 South Pacific tsunami in the Samoan islands. Earth-Science Reviews 107, 38-51.

Riggs, S.R., Cleary, W.J., Snyder, S.W., 1995. Influence of inherited geologic framework on barrier shoreface morphology and dynamics. Marine Geology 126, 213-234.

Robertson, W., Zhang, K., Finkl, C.W., Whitman, D., 2008. Hydrodynamic and geologic influence of event-dependent depth of closure along the South Florida Atlantic Coast. Marine Geology 252, 156-165.

Robertson, W.V., Zhang, K., Whitman, D., 2007. Depth of Closure Derived from Airborne Laser Bathymetry, in: Coastal Sediments' 07. pp. 1877-1885.

Roelvink, J., Stive, M., 1991. Sand Transport on the Shoreface of the Holland Coast: The Dutch Coast: Paper No. 5, in: Coastal Engineering 1990. pp. 1909-1921.

Rosenberger, K.J., Storlazzi, C.D., Dartnell, P., 2019. Morphodynamics of a field of crescentshaped rippled scour depressions: Northern Monterey Bay, CA. Marine Geology 407, 4459.

Różyński, G., Pruszak, Z., Okroj, T., Zeidler, R., 1999. Depth of closure and seabed variability patterns, in: Coastal Engineering 1998. pp. 2926-2939.

Ruggiero, P., Kaminsky, G.M., Gelfenbaum, G., Cohn, N., 2016. Morphodynamics of prograding beaches: A synthesis of seasonal-to century-scale observations of the Columbia River littoral cell. Marine Geology 376, 51-68.

Ruggiero, P., Kaminsky, G.M., Gelfenbaum, G., Voigt, B., 2005. Seasonal to interannual morphodynamics along a high-energy dissipative littoral cell. Journal of Coastal Research $21,553-578$. 
Russell, P.E., 1993. Mechanisms for beach erosion during storms. Continental Shelf Research $13,1243-1265$.

Sabatier, F., Stive, M.J., Pons, F., 2005. Longshore variation of depth of closure on a microtidal wave-dominated coast, in: Coastal Engineering 2004: (In 4 Volumes). World Scientific, pp. 2327-2339.

Safak, I., List, J.H., Warner, J.C., Schwab, W.C., 2017. Persistent shoreline shape induced from offshore geologic framework: effects of shoreface connected ridges. Journal of Geophysical Research: Oceans 122, 8721-8738.

Schupp, C.A., McNinch, J.E., List, J.H., 2006. Nearshore shore-oblique bars, gravel outcrops, and their correlation to shoreline change. Marine Geology 233, 63-79.

Schwab, W.C., Baldwin, W.E., Hapke, C.J., Lentz, E.E., Gayes, P.T., Denny, J.F., List, J.H., Warner, J.C., 2013. Geologic evidence for onshore sediment transport from the inner continental shelf: Fire Island, New York. Journal of Coastal Research 29, 526-544.

Schwab, W.C., Baldwin, W.E., Warner, J.C., List, J.H., Denny, J.F., Liste, M., Safak, I., 2017. Change in morphology and modern sediment thickness on the inner continental shelf offshore of Fire Island, New York between 2011 and 2014: Analysis of hurricane impact. Marine Geology 391, 48-64.

Schwab, W.C., Thieler, E.R., Allen, J.R., Foster, D.S., Swift, B.A., Denny, J.F., 2000. Influence of inner-continental shelf geologic framework on the evolution and behavior of the barrier-island system between Fire Island Inlet and Shinnecock Inlet, Long Island, New York. Journal of Coastal Research 16, 408-422.

Schwartz, R.K., 1975. Nature and genesis of some storm washover deposits. Coastal Engineering Research Center (US).

Schwarzer, K., Bohling, B., Heinrich, C., 2014. Submarine hard-bottom substrates in the western Baltic Sea-human impact versus natural development. Journal of Coastal Research 70, 145-150.

Shand, R.D., Bailey, D.G., Shepherd, M.J., 1999. An inter-site comparison of net offshore bar migration characteristics and environmental conditions. Journal of coastal Research 15, 750-765.

Shawler, J.L., Hein, C.J., Canuel, E.A., Kaste, J.M., Fitzsimons, G.G., Georgiou, I.Y., Willard, D.A., 2019. Tidal erosion and upstream sediment trapping modulate records of land-use change in a formerly glaciated New England estuary. Anthropocene Coasts 2, $340-361$.

Short, A., Jackson, D., 2013. Beach morphodynamics, in: Treatise on Geomorphology. Elsevier, pp. 106-129.

Siringan, F.P., Anderson, J.B., 1994. Modern shoreface and inner-shelf storm deposits off the east Texas coast, Gulf of Mexico. Journal of Sedimentary Research 64, 99-110. 
Slootman, A., Simpson, G., Castelltort, S., de Boer, P.L., 2018. Geological record of marine tsunami backwash: The role of the hydraulic jump. The Depositional Record 4, 59-77.

Stive, M.J.F., De Vriend, H.J., 1995. Modelling shoreface profile evolution. Marine Geology $126,235-248$.

Storlazzi, C., Field, M., 2000. Sediment distribution and transport along a rocky, embayed coast: Monterey Peninsula and Carmel Bay, California. Marine Geology 170, 289-316.

Swift, D.J., Niedoroda, A.W., Vincent, C.E., Hopkins, T.S., 1985. Barrier island evolution, middle Atlantic shelf, USA Part I: Shoreface dynamics. Marine Geology 63, 331-361.

Thieler, E.R., Brill, A.L., Cleary, W.J., Hobbs III, C.H., Gammisch, R.A., 1995. Geology of the Wrightsville Beach, North Carolina shoreface: Implications for the concept of shoreface profile of equilibrium. Marine Geology 126, 271-287.

Thieler, E.R., Foster, D.S., Himmelstoss, E.A., Mallinson, D.J., 2014. Geologic framework of the northern North Carolina, USA inner continental shelf and its influence on coastal evolution. Marine Geology 348, 113-130.

Thieler, E.R., Pilkey Jr, O.H., Cleary, W.J., Schwab, W.C., 2001. Modern sedimentation on the shoreface and inner continental shelf at Wrightsville Beach, North Carolina, USA. Journal of Sedimentary Research 71, 958-970.

Thomas, T., Phillips, M., Williams, A., Jenkins, R., 2011. A multi-century record of linked nearshore and coastal change. Earth Surface Processes and Landforms 36, 995-1006.

Trowbridge, J., 1995. A mechanism for the formation and maintenance of shore-oblique sand ridges on storm-dominated shelves. Journal of Geophysical Research: Oceans 100, 1607116086.

Valiente, N.G., Masselink, G., Scott, T., Conley, D., 2017. Depth of closure along an embayed, macro-tidal and exposed coast: a multi-criteria approach. Coast. Dyn 12111222.

Valiente, N.G., Masselink, G., Scott, T., Conley, D., McCarroll, R.J., 2019. Role of waves and tides on depth of closure and potential for headland bypassing. Marine Geology 407, $60-75$.

Valvo, L.M., Murray, A.B., Ashton, A., 2006. How does underlying geology affect coastline change? An initial modeling investigation. Journal of Geophysical Research: Earth Surface 111.

Van de Meene, J.W., van Rijn, L.C., 2000a. The shoreface-connected ridges along the central Dutch coast - part 1: field observations. Continental Shelf Research 20, 2295-2323.

Van de Meene, J.W., van Rijn, L.C., 2000b. The shoreface-connected ridges along the central Dutch coast - part 2: morphological modelling. Continental Shelf Research 20, 23252345. 
Van der Molen, J., Van Dijck, B., 2000. The evolution of the Dutch and Belgian coasts and the role of sand supply from the North Sea. Global and Planetary Change 27, 223-244.

Verwaest, T., Houthuys, R., Roest, B., Dan, S., Montreuil, A.-L., 2020. A Coastline Perturbation caused by Natural Feeding from a Shoreface-connected Ridge (Headland Sint-André, Belgium). Journal of Coastal Research 95, 701-705.

Vincent, C.E., Young, R.A., Swift, D.J., 1983. Sediment transport on the Long Island shoreface, North American Atlantic Shelf: role of waves and currents in shoreface maintenance. Continental Shelf Research 2, 163-181.

Vis-Star, N.C., De Swart, H., Calvete, D., 2007. Effect of wave-topography interactions on the formation of sand ridges on the shelf. Journal of Geophysical Research: Oceans 112.

Wijnberg, K.M., 2002. Environmental controls on decadal morphologic behaviour of the Holland coast. Marine Geology 189, 227-247.

Wright, L., Boon, J., Kim, S., List, J., 1991. Modes of cross-shore sediment transport on the shoreface of the Middle Atlantic Bight. Marine Geology 96, 19-51.

Wright, L., Short, A., Green, M., 1985. Short-term changes in the morphodynamic states of beaches and surf zones: an empirical predictive model. Marine geology 62, 339-364.

Wright, L., Short, A.D., 1984. Morphodynamic variability of surf zones and beaches: a synthesis. Marine geology 56, 93-118.

Yoshikawa, S., Nemoto, K., 2014. The role of summer monsoon-typhoons in the formation of nearshore coarse-grained ripples, depression, and sand-ridge systems along the Shimizu coast, Suruga Bay facing the Pacific Ocean, Japan. Marine Geology 353, 84-98.

Zecchin, M., Catuneanu, O., Caffau, M., 2019. Wave-ravinement surfaces: classification and key characteristics. Earth-science reviews 188, 210-239. 